2. HISTORIA DEL PENSAMIENTO JURÍDICO Y POLÍTICO 

Revista de Estudios Histórico-Jurídicos

[Sección Historia del Pensamiento Jurídico y Político]

XXXIII (Valparaíso, Chile, 2011)

[pp. 227 - 272]

\title{
LA LIBERTAD DE CONCIENCIA Y DE RELIGIÓN EN LA ILUSTRACIÓN FRANCESA: \\ El Modelo de Voltaire y de la "EnCyClopédie"
}

["Freedom of Conscience and Religion in the French Enlightenment: The Model of Voltaire and the 'Encyclopédie'”]

\author{
Julio Alvear Téllez* \\ Universidad del Desarrollo, Santiago de Chile
}

\begin{abstract}
RESUMEN
En el concepto de la Ilustración francesa la libertad de conciencia y de religión no es un derecho amplio y neutral. Los términos apuntan a un significado más restringido de lo que a primera vista se sugiere. En los escritos de Voltaire y la Encyclopédie dicha libertad se reputa por esencia y por sistema desvinculada del Dios cristiano y de su ley. Son la vena anti-cristiana, el agnosticismo religioso y el escepticismo metafísico los que vivifican el fundamento de esta libertad moderna.

Palabras clave

Libertad de conciencia - Libertad de culto - Tolerancia - Ilustración - Voltaire - Encyclopédie.
\end{abstract}

\section{ABSTRACT}

The French Enlightenment does not think that freedom of conscience and religion is a broad and neutral right. The terms depict a meaning narrower than that which, at first sight, is suggested. The writings of Voltaire and the Encyclopédie consider said freedom, per essence and per system, as separated from the Christian God and His law. The anti-Christian disposition, the religious agnosticism and the metaphysical skepticism are the basis for this Modern freedom.

\section{KeYwords}

Freedom of conscience - Freedom of worship - Tolerance - Enlightenment Voltaire - Encyclopédie.

ReCibido el 30 de diciembre de 2010 y ACEPTADO el 2 de julio de 2011

* Profesor-Investigador de la Facultad de Derecho de la Universidad del Desarrollo. Dirección postal: Universidad del Desarrollo, Facultad de Derecho, Av. La Plaza 680, Las Condes, Santiago, Chile. Correo electrónico: jalvear@udd.cl 


\section{INMANENTISMO ANTI-CRISTIANO, TOLERANCIA Y LIBERTAD DE CONCIENCIA}

Desde el ángulo de la génesis del pensamiento político moderno se puede afirmar que la Ilustración francesa llevó a cabo le procès du christianisme ${ }^{1}$ como arma necesaria para "liberar" al orden político de todo referente a una verdad y normatividad trascendentes, a fin de recomenzar desde la voluntad humana desligada la creación ex nihilo de la sociedad y del Estado. Montesquieu, Voltaire, Rousseau y los autores de la Encyclopédie (Diderot, Romilly, Jaucourt, entre otros) representan en diversos grados las figuras de relieve de este espectáculo, en la medida en que hicieron de la libertad de conciencia y de religión el pivote sobre el que gira esta desligación.

En este ámbito, la Ilustración francesa ensayó la destrucción de los puentes que la conciencia humana había creado con la verdad cristiana (la fe y la ley divino-natural), negando su contenido objetivo y la misma posibilidad formal de conocerla. Con trascendencia no hay libertad. Arrumbar entonces la verdad trascendente que fue dada y transmitida a Europa por la Iglesia fue el objetivo.

Es cierto que el Iluminismo reconoce matices diversos según su desenvolvimiento en Inglaterra, Francia o Alemania. La Ilustración inglesa tiene una fuerte vertiente empírica, tiende al deísmo y desconoce el carácter revelado de la religión cristiana ${ }^{2}$. La Ilustración alemana es racionalista, admiradora del humanismo y par-

${ }^{1}$ El término es clásico y pertenece a Paul Hazard, La Pensée européenne au XVIIIe siècle, de Montesquieu à Lessing (1946, edición Paris, Librairie Arthème Fayard, 1979), pp. 7-81 [versión electrónica del 2005 de la Bibliothèque Paul-Émile Boulet de l'Université du Québec]. Para la edición española: Hazard, Paul, El pensamiento europeo en el siglo XVIII (traducción castellana de Julián Marías, Madrid, Alianza, 1985), pp. 15-91. A su estudio histórico dedica todo el primer capítulo del libro citado El autor resalta como elementos del proceso ilustrado al cristianismo la crítica universal de la tradición religiosa y filosófica y de las instituciones católicas, la depreciación de Cristo, la negación del concepto y del contenido de la religión revelada, el recurso a las falsas imputaciones y el progreso de la incredulidad en las elites de la época. Sobre la Ilustración, hay que discernir las obras destinadas a propagar a-críticamente sus ideas de aquellas que emprenden un trabajo filosófico o histórico serio de análisis con referencia a las fuentes. Un ejemplo del primer tipo en TEOdorov, Tzvetan, L'Esprit des Lumières (Paris, Laffont, 2006). Obras representativas de lo segundo en ADAM, Antoine, Le Mouvement philosophique dans la premiere moitie du XVIIIe siècle (Paris, S.e.d.e.s., 1967); Gusdorf, Georges, Les Sciences humaines et la pensée occidentale (Paris, Payot, 1971), IV: Les principes de la pensée au siècle del lumières; GUSDORF, Georges, Les Sciences humaines et la pensée occidentale (Paris, Payot, 1972), V: Dieu, la nature, l' homme au siècle des lumières; DE Viguerie, Jean, Histoire et Dictionnaire du temps des Lumières (Paris, Laffont, 1995); MARTIN, Xavier, Nature humaine et Révolution française: Du siècle des Lumières au Code Napoleón (Paris, Dominique Martin Morin, 2002). Sobre las relaciones entre la Ilustración y la Revolución Francesa son todavía útiles las dos obras de referencia de Mornet: MornEt, Daniel, La Pensée française au XVIIIe siècle (Paris, Colin, 1926); EL MISMO, Les origines intellectuelles de la Révolution française, 1715-1787 (Paris, Colin, 1933). Ambas se encuentran traducidas al español: Mornet, Daniel, El pensamiento francés en el siglo XVIII: el trasfondo intelectual de la Revolución francesa (Madrid, Encuentro, 1988); EL MISMO, Los orígenes intelectuales de la Revolución Francesa (Buenos Aires, Paidos, 1969).

${ }^{2}$ Estermann, Josef, Historia de la filosofía (Traducción Quito, Ed. Salesiana, 1997), III, $2^{a}$ parte, p. 12. Estermann caracteriza el iluminismo inglés por medio de la filosofía de la 
tidaria de la "racionabilidad" del cristianismo, entendido como religión universal fundamentalmente moral ${ }^{3}$. La Ilustración francesa es pugnazmente anti-católica, dirige sus dardos contra el principio de autoridad religioso y político y tiende al materialismo y al ateísmo ${ }^{4}$.

Empero, si se desciende al detalle de las fuentes, se constata tras estos matices diferenciales un denominador común: la negación filosófica de la verdad cristiana (en sus caracteres específicos de revelada, salvífica y magisterial) y el rechazo político a su calidad histórica de ley trascendente orientadora del orden político. En otros términos, la vía especulativa abierta por la Ilustración queda embridada por un impulso político: la sustitución del Regnum Dei por el regnum hominis, lo que en términos de pretensión jurídica significa denegar a la fe cristiana el derecho de regir/inspirar el orden político y la moral pública. La Ilustración puede ser caracterizada, en este sentido, como "el desplazamiento de atención hacia el hombre, la apropiación crítica de las representaciones de Dios y su transformación constitutiva por parte de la razón moderna" 5 .

A este propósito escribe Pierre Manent que las armas de la libertad moderna fueron forjadas durante los siglos de la Ilustración en un áspero combate contra el cristianismo y particularmente contra la Iglesia Católica ${ }^{6}$.

$\mathrm{Y}$ es que la libertad ilustrada de conciencia y de religión no es un concepto

religión y de la filosofía moral. En filosofía de la religión, es deísta y propugna la religión natural a partir de Edward Cherbury (1583-1648), al que siguen John Toland (1670-1722), Mattew Tindal (1656-1733) y el vizconde de Bolingbroke (1678-1751). En filosofía moral recalca la independencia de la ética respecto de la ley divino-natural con Anthony Shaftesbury (1671-1713), Francis Hutcheson (1694-1747) y Bernhard de Mandeville (1670-1733). Ibíd., pp. 12-13.

${ }^{3}$ Ibíd., p. 12. Estermann distingue tres fases: (a) Racionalismo metafísico, que asume una confianza ilimitada en la razón humana (Christian Wolf, 1679-1728); (b) Tiempo del deísmo y de la religión natural, con influencia de la ilustración inglesa y francesa: Federico II El Grande (1712-1786); Hermann Samuel Reimarus (1694-1768) que concibe el mundo como única revelación de Dios; Moses Mendelssohn (1729-1786) que sostiene el judaísmo racionalista como religión natural; y Gotthold Ephraim Lessing (1729-1781) que propaga el indiferentismo religioso; (c) Fase auto-crítica de los fundamentos de la Ilustración, en la que prolifera la reivindicación de los sentimientos religiosos por obra de Johann Georg Hamann (1730-1788), Johann Gottfried Herder (1744-1803) y Friedrich Heinrich Jacobi (1743-1819). Ibíd., pp. 20-22.

${ }^{4}$ Ibíd., p. 12. Las tendencias anti-clericales y anti-religiosa se mezclan con otras anti-teístas, “en una polémica incansable contra la Iglesia católica y el Antiguo Régimen”: ibíd., p. 13. En la Ilustración francesa destacan el escepticismo de Pierre Bayle (1647-1706), el laicismo de Montesquieu (1689-1755), el hilozoísmo de Pierre Louis Moreau de Maupertuis (1698-1759), el deísmo de Voltaire (1694-1778), el ateísmo de Denis Diderot (1713-1784), el materialismo ilustrado de Jean le Rond D’Alambert (1717-1783), Julien Offroy de La Mettrie (1709-1751), Paul d'Holbach (1723-1789) y Pierre Cabanis (1757-1808). Aún teniendo en cuenta sus conflictos con figuras de la Ilustración, también hay que incluir en ésta a Jean Jacques Rousseau (1712-1778). Ibíd., pp. 16-19.

${ }^{5}$ Villacañas Berlanga, José Luis, Historia de la razón y giro copernicano, en Logos. Anales del Seminario de Metafísica, 37 (Madrid, 2004), p. 71.

${ }^{6}$ Manent, Pierre, Histoire intellectuelle du libéralisme: dix leçons (1987, rééd. Paris, Hachette, 2004). Utilizamos la edición española: Id., Historia del pensamiento liberal (traducción Buenos Aires, Emecé, 1990), pp. 12-13. 
neutral, tal como hoy día se le presenta. En cuanto pretende reducir la verdad cristiana a mera opinión, se fundamenta en presupuestos filosóficos de carácter epistemológico, metafísico, teológico, político y religioso-práctico específicos. Tales presupuestos son respectivamente los siguientes: $i$ ) La subjetividad respecto a la verdad del orden del ser; ii) Las ideas no existen en cuanto expresan las esencias de las cosas, sino que son sensaciones transformadas; iii) Lo sobrenatural repugna a la razón; religión revelada y razón son inconciliables; iv) El estado social y político no es natural al hombre; y $v$ ) El odio al Papado ${ }^{7}$.

Este último punto es compartido netamente con el protestantismo preilustrado, al que la Ilustración agrega, como motor de la libertad de conciencia moderna, el rompimiento formal con la religión revelada ${ }^{8}$.

Los philosophes adoctrinan sobre la libertad de conciencia a través de la tolerancia. Jean de Viguerie resume este concepto tan caro al Iluminismo en cuatro preceptos: $i$ ) no hacer a los demás lo que no nos gustaría padecer; ii) toda verdad es subjetiva, y, por tanto, nadie tiene derecho a imponer su norma; iii) toda religión no es más que una opinión entre otras; y iv) el Estado no tiene por qué intervenir en las cuestiones que implican una definición de la salvación eterna?.

Viguerie defiende la tesis de que la tolerancia ilustrada es un concepto engañoso, un arma de propaganda. Es porque ninguna religión es verdadera que se debe tolerar la difusión de los ataques contra ella. Se deben tolerar las religiones no porque sean buenas, sino porque no ameritan que alguien se bata por ellas, y especialmente por el catolicismo, que es la peste de la humanidad y necesita ser erradicado sin ninguna tolerancia ${ }^{10}$.

De esta manera, el escepticismo metafísico, el agnosticismo religioso, el naturalismo, el deísmo y la incredulidad -manifestaciones del inmanentismo anti-cristiano moderno- son las bases más recurridas para justificar la libertad ilustrada de conciencia y de religión. A continuación probaremos la tesis en dos modelos de la Ilustración francesa: el presentado por Voltaire y el diseñado por la Encyclopédie

${ }^{7}$ DE Viguerie, Jean, cit. (n. 1), p. 268. El autor señala expresamente los puntos i), iii) y $v$ ); el resto se induce de su análisis. La caracterización se aplica sobre todo a la Ilustración francesa, pero, mutatis mutandis, es extensible a la inglesa, que la precede, y a la alemana, sobre todo en los puntos iii), iv) y, a su manera $v$ ).

${ }^{8}$ Jean de Viguerie estudia el aspecto anti-cristiano del Iluminismo francés. Hace un elenco de sus principales afirmaciones: para los philosophes-que o eran ateos o deístas- el Dios de la Revelación cristiana debe ser rechazado; Dios no tiene nada que ver con las religiones positivas; tales religiones no valen nada, son inconsistentes; no existe ninguna religión verdadera; el cristianismo no es verdadero; los dogmas del cristianismo son absurdos, sus libros sagrados contradictorios. Ibíd., pp. 272-274.

${ }^{9}$ Ibíd., pp. 1.405- 1.406.

${ }^{10}$ DE Viguerie, Jean, cit., pp. 274-275, con amplias citas especialmente de los ilustrados franceses. A nivel divulgativo, SÉvillia, Jean, Historiquement correct. Pour en finir avec le passé unique (Paris, Perrin, 2003). Usamos la edición española: Históricamente incorrecto (traducción Madrid, Ciudadela, 2006), pp. 169 ss., con citas suficientemente ilustrativas. 


\section{François Marie Arouet alias Voltaire (1694-1778)}

Voltaire ${ }^{11}$ es uno de los pensadores ilustrados que con más energía divulgaron el concepto de tolerancia religiosa, como presupuesto de la libertad de conciencia y de cultos. Pero, a la vez, constituye un ejemplo elocuente de la fundamentación de tales categorías en el escepticismo metafísico, el agnosticismo religioso y el repudio al cristianismo.

Jean de Viguerie, en su Histoire et Dictionnaire du temps des Lumières, retrata el pensamiento volteriano tomando en cuenta no solo sus obras filosóficas, históricas, literarias y panfletarias, sino también su correspondencia personal que alcanza la impresionante cifra de diez mil cartas. Permeado por un concepción materialista y empirista del ser humano y del conocimiento, considera que el cristianismo es por esencia un fanatismo y que no se puede a la vez ser cristiano y ser tolerante ${ }^{12}$.

\section{El dios de Voltaire.}

Entre los estudiosos de Voltaire se discute su concepción religiosa considerando el pensamiento en su conjunto. No hay ninguna duda sobre su premisa de que no existe la verdad divina, como revelada, salvífica e infalible. Pero es dudoso si este escepticismo es sólo metafísico o también epistemológico ${ }^{13}$. Nadie disputa su espíritu iconoclasta con relación al cristianismo y su furor contra el catolicismo ${ }^{14}$.

${ }^{11}$ Sobre Voltaire, las obras de referencia más importantes son: NoYEs, Alfred, Voltaire (London, Sheed \& Ward, 1936); Delumeau, Jean, Le catholicisme entre Luther et Voltaire (Paris, P. U.F, 1971); Desnoiresterres, Gustave, Voltaire et la Société au XVIIIe siècle (Paris, Didier, 1867-1876), 8 vols. [ed. digital en: [http://www.voltaire-integral.com/zEtudes/desnoiresterres. htm]; Besterman, Theodore y otros, Studies on Voltaire and the Eighteenth Century (Oxford, The Voltaire Foundation, 1956-2010), 500 vols.; POMEAU, René, Voltaire en son temps (Oxford - Paris, Voltaire Foundation-Fayard, 1985-1994), 5 vols. Sobre la vida de Voltaire y su tiempo: Peyrefitte, Roger, Voltaire, sa jeunesse et son temps (Paris, Albin Michel, 1985); Pomeau, René (editor), Voltaire en son temps (Paris, Fayard, 1995), 2 vols.; GALlo, Max, Moi, jécris pour agir: vie de Voltaire (Paris, Fayard, 2008); Trousson, Raymond, Voltaire 1778-1878 (Paris, PUPS, 2008). Sobre su pensamiento, VERSAILle, André (editor), Dictionnaire de la pensée de Voltaire (Bruxelles, éditions Complexe, 1994); WATERLOT, Ghislain, Voltaire: le procureur des Lumières (Paris, Michalon, 1996); LePAPE, Pierre, Voltaire le conquerant. Naissance des intellectuels au siècle des Lumiéres. Essai (Paris, Seuil, 1997); Trousson, Raymond y Vercruysse, Jeroom, Dictionnaire général de Voltaire par lui-même (Paris, Champion, 2003). Sobre la imagen mítica de Voltaire, Goldzink, Jean, Voltaire, la légende de saint Arouet (Paris, Gallimard, 1989) y Martin, Xavier, Voltaire méconnu: aspects cachés de l' humanisme des Lumières (1750-1800) (Paris, Dominique Martin Morin, 2006). En el medio español, Pujol, Carlos, Voltaire, Palabra, Madrid, 1999, aunque depende fundamentalmente de Pomeau.

${ }^{12}$ DE Viguerie, Jean, cit., s.v. Voltaire, pp. 1448-1449.

${ }^{13}$ Voltaire escribe lapidariamente en su cuaderno de notas en inglés: "God cannot be proved, nor denied, by the mere force of our razon" ("Dios no puede ser ni probado, ni negado, con las solas fuerzas de nuestra razón”). La frase es reproducida por BESTERMAN, Theodore, Voltaire's Notebooks (Gonève, Publications de l'Institut et Musée Voltaire, 1952), citado por Balet Roca, Sebastián, Le deisme anglais et le probleme de la religion de Voltaire, en Cuadernos de Investigación Filológica, 6 (Logroño, 1980), p. 31.

${ }^{14}$ Norman L. Torrey destaca en su Voltaire and the English Deists (New Haven, Yale University Press, 1930, reimp. 1963), un “deísmo constructivo” y un “deísmo crítico”. Este 
Pero cabe la interrogante sobre el preciso lugar que ocupa esta animadversión en su doctrina de la tolerancia. Existe consenso acerca de sus convicciones básicamente deístas, pero se presta a divergencia el grado de evolución hacia posturas próximas al ateísmo ${ }^{15}$.

Quizás lo que mejor califica el espíritu del filósofo de Ferney es el dictado de deísmo en rebelión, tal como se manifiesta en el Poème sur le désastre de Lisbonne ${ }^{16}, \mathrm{o}$

último se caracteriza por el ataque al cristianismo considerado como un obstáculo al progreso racional y moral del hombre y que en Voltaire encuentra su fuente en los libertinos franceses como Rabelais, Montaigne, Gassendi o La Mothe le Vayer y en los deístas ingleses como Toland, Woolston, Collins y Annet.

${ }^{15}$ Las dificultades para fijar el pensamiento definitivo de Voltaire sobre Dios son muchas. Vr. gr., el Traité de Métaphysique, escrito en 1734, está en gran parte dedicado al tema, pero es más bien un tratado de la $d u d a$ acerca del orden del ser y del acceso metafísico a Dios: Voltaire, Traité de Métaphysique, en Oeuvres complètes de Voltaire (Baudouin Frères, París), XLIII: Philosohie, 1, pp. 117-197. La obra se inicia mostrando una vacilación fundante acerca de la posibilidad de saber qué es el hombre, dada la variabilidad intelectual, moral, psicológica, física y étnica que existe entre ellos y los desacuerdos filosóficos sobre la naturaleza humana. Ibíd., 1825 , cap. $1^{\circ}$, pp. $122-125$. El capítulo $2^{\circ}$ se pregunta si hay un Dios e inicia el examen de la cuestión constatando los muchos conceptos que hay sobre Él. Enuncia un elenco de razones a favor de Su existencia, para formular a continuación las objeciones, seguidas de una réplica. Ibíd., II, pp. 125-143. Metafísicamente hablando los argumentros de lado y lado son bastante pobres (materializa por ejemplo la causa primera eficiente, de tal modo que plantea la dificultad de que Dios no puede crear de la nada el mundo material, porque la nada, nada es. Luego, tiene que crearlo desde su propia sustancia [...] (i!). Ibíd., II, cap. $1^{\circ}$, pp. 131). En los argumentos morales -la existencia del mal- Voltaire es más lúcido. Lo interesante es que las objeciones contra Dios siempre son presentadas con más sutileza y mejor poder persuasivo que las razones a su favor. Al final, Voltaire se decanta a favor de la existencia de Dios, pero con el bajo contínuo de un escepticismo poco contenible: "Dans l'opinion qu'ily a un Dieu, il se trouve des dificultes; mais dans l'opinion contraire, il y a des absurdités" "En la opinión de que hay un Dios, se cae en muchas dificultades; en la opinión que lo niega, se cae en un absurdo"). Id., II, p. 144. En el capítulo III opta por sostener que todas las ideas provienen de los sentidos, con lo que, en rigor, hace imposible el acceso metafísico a un Dios trascendente y personal. Id., III, pp. 144-150. Una notable síntesis entre la alternativa del Voltaire "deísta" y del Voltaire cercano al "ateísmo", en Sebastián Balet Roca, cit., pp. 29-38, en donde evalúa las distintas posiciones. Para una visión panorámica del problema, HAZARD, Paul, cit., pp. 353-364, y más ampliamente, Pomeau, René, La Religión de Voltaire (Paris, Nizet, 1956).

${ }^{16} \mathrm{El}$ Poème sur le désastre de Lisbonne fue compuesto en diciembre de 1755 con ocasión del terremoto que destruyó la ciudad el 1 de noviembre de 1755. Salió a luz al año siguiente. Con fino arte literario, Voltaire sugiere la tesis filosófica de que el mal que existe en el mundo no podría ser realidad si el Dios bueno y providente de los cristianos existiera, porque la idea de un castigo divino es insensata y debe desecharse: "Aux cris demi-formés de leurs voix expirantes/ Au spectacle effrayant de leurs cendres fumantes/ Direz-vous: 'C'est l'effet des éternelles lois/ Qui d'un Dieu libre et bon nécessitent le choix ?'/ Direz-vous, en voyant cet amas de victimes: / Dieu s'est vengé, leur mort est le prix de leurs crimes ?'/ Quel crime, quelle faute ont commis ces enfants/ Sur le sein maternel écrasés et sanglants ?/ Lisbonne, qui n'est plus, eut-elle plus de vices/ Que Londres, que Paris, plongés dans les délices:/ Lisbonne est abîmée, et l'on danse a Paris" : "Frente a los gritos, a medio formar, de sus voces moribundas/ y frente al espantoso espectáculo de sus humeantes cenizas/¿Dirán ustedes: "Es el efecto de las eternas leyes/que, de un Dios libre y bueno, necesitan la decisión”? ¿Dirán ustedes, al ver ese montón de víctimas: “ ¿Se ha vengado Dios; su muerte paga sus crimenes?" ¿Qué crimen, qué culpa cometieron esos niños/sobre el seno materno aplastados y sangrientos?/ ¿Tuvo Lisboa, que ya no es, más vicios/ que Londres, que París, en los 
el de deismo utilitario manifestado en el Dictionnaire Philosophique (artículos Athée,Athéisme,Dieu), que estudiaremos más adelante. Este tipo de deísmo es el que plasma, la noción volteriana de Dios, de la religión y del hombre ${ }^{17}$.

Dentro de esta rebelión explosiva cabe notar su intolerancia virulenta contra el catolicismo. Probablemente nadie como Paul Hazard ha descrito en pocas líneas aquella actitud, vena del anti-clericalismo moderno, cuyo espíritu de calumnia, así como sus excesos y violencias, le distanciaron de las personalidades más moderadas de la Ilustración, como Genovesi, Verri, Nicolai, Schlegel o Elberhardt ${ }^{18}$. Muchos vieron en él un genio del odio ${ }^{19}$. El mismo Diderot le llamó el Anti-Cristo ${ }^{20}$. Y, sin embargo, Voltaire es considerado hoy el símbolo ilustrado de la defensa de la tolerancia y de la libertad de conciencia moderna. Y la verdad es que, por un lado, predicaba la tolerancia de los católicos hacia las nuevas ideas y, por otro, la intolerancia de los ilustrados hacia el catolicismo, según su famoso apóstrofe "écrasez l'infame"21.

El año 1736, Voltaire escribe su Examen important de Milord Bolingbroke ou le tumbeau du fanatisme. Es una diatriba contra el Antiguo Testamento ${ }^{22}$ y el Evangelio $^{23}$, contra Moisés ${ }^{24}$, contra los profetas ${ }^{25}$, contra los judíos como pueblo

deleites hundidas?/ Lisboa queda hundida, y en París se baila". Voltaire, Poème sur le désastre de Lisbonne ou Examen de cet axiome, tout est bien [edición digital en: http://fr.wikisource.org/ wiki/Po\%C3\%A8me_sur_le_d\%C3\%A9sastre_de_Lisbonne], líns.13-23.

${ }^{17}$ Es la tesis de Balet Roca, que acuña el término deísmo en rebelión y deísmo utilitario. $\mathrm{Al}$ respecto oberva: "El (Voltaire) acepta, en principio, la existencia de Dios, pero no ignora que existen las más graves dificultades. De ese Dios uno puede afirmar su existencia, pero no sabe nada más: es en todo caso inaccesible al hombre [...]. En cuanto al alma, no acepta esta entidad metafísica. No cree tampoco en la inmortalidad personal. Y rechaza, evidentemente, toda religión revelada [...]. Las cuestiones metafísicas no le interesan [...] lo que le interesa es el hombre. Es por su humanidad que lucha [...] y en su lucha contra la intolerancia, el fanatismo y la injusticia, se revela contra la injusticia de la Providencia, que él acepta provisoriamente". Balet Roca, Sebastián, cit., p. 38.

${ }^{18}$ Hazard, Paul, cit. (n. 1), pp. 362-364.

19 "Voltaire ist der Genie des Hasses", citado por KorfF, Hermann Augus, Voltaire im literarischen Deutschland des 18 (Heidelberg, Zweites Buch, 1918), pp. 235 ss., en HaZARD, Paul, cit. (n. 1), p. 363.

${ }^{20}$ Ibíd.:

${ }^{21} \mathrm{La}$ infame que había que aplastar era particularmente la Iglesia Católica, pero no excluía a ninguna de las confesiones cristianas, abarcándolas a todas con el epíteto de la "secta" de los cristianos. Un análisis del significado de la frase a través de la correspondencia volteriana y de los estudios sobre el tema, en OCÁrIZ, Fernando, Voltaire. Tratado sobre la tolerancia (Madrid, Crítica-Emesa, 1979), pp. 47-51.

${ }^{22}$ Voltaire, Examen important de Milord Bolingbroke ou le tumbeau du fanatisme, en Oeuvres de Voltaire (1736, edición Paris, Pourrat Frères, 1839), II: Philosohie, cap. 1², pp. 94-97; caps. $3^{\circ}$ y $4^{\circ}$, pp. $103-109$ y cap. $6^{\circ}$, pp. 112-114.

${ }^{23}$ Ibíd., cap. $13^{\circ}$, pp. $152-160$.

${ }^{24}$ Ibíd., cap. $2^{\circ}$, pp. $98-102$.

${ }^{25}$ Ibíd., cap. $9^{\circ}$, pp. 124-129. 
electo $^{26}$, contra los primeros cristianos ${ }^{27}$, contra San Pablo ${ }^{28}$, contra los mártires ${ }^{29}$, contra los Padres de la Iglesia ${ }^{30}$, contra el Papado ${ }^{31}$ y contra el propio Cristo ${ }^{32}$. La conclusión es significativa: "Je conclus que tout homme sensé, tout homme de bien, doit avoir la secte chrétienne en horreur" 33

Pero Voltaire destruye para construir. Hay una cierta mística religiosa deísta en él. En 1768 escribe la Profession de foi des Theistes ${ }^{34}$. En el opúsculo no teme entrar en contradicción consigo mismo cuando afirma -en tono dogmático- que hay una sola religión verdadera (el humanitarismo ilustrado) y que el resto -todas las que hasta la fecha han aparecido sobre la tierra- son falsas. El paso previo es mostrar cómo las religiones judeo-mosaica y cristiana equivalen a la superstición. Han deformado la verdadera fe en Dios, con dogmatismos y ritos que impiden que los adorateurs d'un Dieu ami des hommes establezcan la paz sobre la tierra. El cristianismo debe ser desechado por falsario:" Le christianisme, tel qu'il est, et tel qu'il n'aurait pas dî̀ être, se fonda sur les plus honteuses fraudes: sur cinquante évangiles apocryphes; sur les constitutions apostoliques reconnues pour supposées; sur des fausses lettres de Jésus, de Pilate, de Tibère, de Sénèque, de Paul; sur les ridicules récognitions de Clément; sur l imposteur qui a pris le nom d' Hermas; sur l imposteur Abdias, limposteur Marcel, limposteur Hégésippe; sur la supposition de misérables vers attribués aux sibylles; et après cette foule de mensonges vient une foule d'interminables disputes" 35 .

La única "religión verdadera", si cabe, es el theísmo,que a lo largo de su opúsculo Voltaire describe a la manera de un deísmo moralista ${ }^{36}$, superador de las fantasías de la revelación cristiana: "Notre religion, ô grand homme! est donc la seule qui soit universelle, comme elle est la plus antique et la seule divine. Nations égarées dans le labyrinthe de mille sectes différentes, le théisme est la base de vos édifices fantastiques; c'est sur notre vérité que vous avez fondé vos absurdités. Enfants ingrats, nous sommes

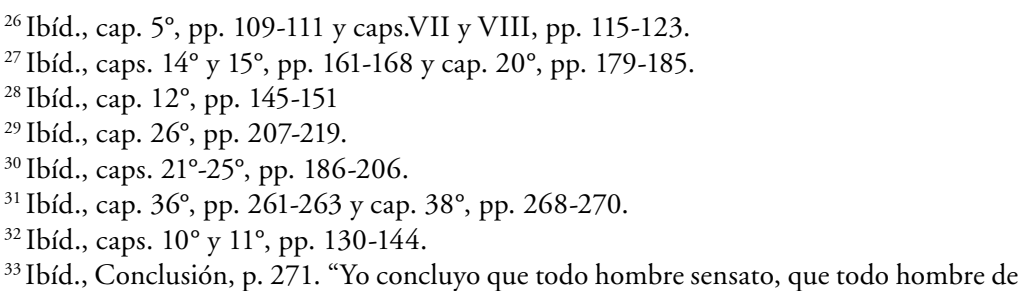
bien, debe tener horror a la secta de los cristianos".

${ }^{34}$ Voltaire, Profession de foi des Theistes, en Oeuvres de Voltaire (1768, edición Paris, Pourrat Frères, 1839), II: Philosohie, pp. 391-427. El opúsculo está dedicado al Rey de Prusia.

${ }^{35}$ Ibíd., p. 422]: "El cristianismo, tal cual es, y tal como no ha dejado de ser, se funda en los más profundos fraudes: sobre cincuenta evangelios apócrifos; sobre constituciones apostólicas reconocidas como supuestas; sobre falsas cartas de Jesús, de Pilatos, de Tiberio, de Séneca, de Pablo; sobre los ridículos reconocimientos de Clemente, sobre el impostor que tomó el nombre de Hermas, sobre el impostor Abdías, el impostor Marcelo, el impostor Hegesipo; sobre la suposición de miserables versos atribuidos a las sibilas; y después de esta sarta de mentiras viene una masa interminable de disputas".

${ }^{36}$ Ibíd., pp. 418-420. 
vos pères, et vous nous reconnaissez tous pour vos pères quand vous prononcez le nom de Dieu" 37 .

Voltaire afirma estar convencido de tener el patrimonio exclusivo de la auténtica y única "religión", al punto de que habla como sacerdote o padre (père), consolando o condenando. Conoce el "dogma", que en este caso se resuelve en el humanitarismo o culto al hombre, como indica la última frase de la Profession que proclama (con letra mayúscula): Résignation,et non Gloire, a Dieu ${ }^{38}$.

\section{La doctrina de la tolerancia,rúbrica artera de la libertad de conciencia y de} religión.

¿Cómo es posible convertirse en símbolo de la tolerancia moderna, promoviendo la intolerancia contra el cristianismo que, en su época, profesaba la casi totalidad de la población europea? ¿Cómo es factible proclamar la libertad de conciencia y de religión, negando la legitimidad de la libertas christiana?

De un texto de la Profession de foi des Theistes puede inducirse que la tolerancia es la llave que abre el respeto a la libertad de conciencia y de religión, y ésta es el puente que permite al Estado renunciar al influjo de la fe cristiana en la vida pública, pues ésta es una mentira que no encubre sino avaricia, hipocresía y ambición: "[...] pendant que l avarice, L ambition, l hypocrisie,oppriment encore les consciences dans tant de provinces de notre Europe: tant il est vrai que le théisme est doux, et que la superstition est barbare" 39 .

¿Por qué el teísmo es dulce? Porque, entre otras cosas, asegura la libertad de conciencia moderna. Por ejemplo, "bendice" la Constitución de Pennsylvania, reconocida por Carlos II de Inglaterra, que garantiza que "la liberté de conscience étant un droit que tous les hommes ont reçu de la nature avec lexistence" ${ }^{40}$. De ella deriva la libertad de cultos. "Soyez béni à jamais,sire", exclama Voltaire, remedando la consagración de la monarquía católica: "Vous avez établi chez vous la liberté de conscience" $^{\text {"41. }}$.

En el Traité sur la Tolérance, publicado en $1763^{42}$, el filósofo de Ferney hace una apología más o menos explícita del escepticismo dogmático, así como del

${ }^{37}$ Ibíd, pp. 394-395: "Nuestra religión, o gentilhombre!, es la única universal, la más antigua y la única divina. Oh! Naciones extraviadas en el laberinto de miles de sectas diferentes, el teísmo es la base de vuestros edificios fantásticos; es sobre nuestra verdad que ustedes fundan sus absurdos. Hijos ingratos, nosotros somos vuestros sacerdotes, y todos nos reconocerán como tales cuando pronuncien el nombre de Dios".

${ }^{38}$ Ibíd., p. 428.

${ }^{39}$ Ibíd., p. 424: "Mientras la avaricia, la hipocresía y la ambición oprimen todavía las conciencias en tantas provincias de nuestra Europa, se hace patente que el teísmo es dulce y que la superstición es bárbara”

${ }^{40}$ Ibíd., p. 423. "La libertad de conciencia es un derecho que todos los hombres han recibído de la naturaleza con la existencia”.

${ }^{41}$ Ibíd.: "Sean benditos por siempre, señor, los que han establecido (en su país) la libertad de conciencia”.

${ }^{42}$ Voltaire, Traité sur la Tolérance a l'occasion de la mort de Jean Calas, 1763, en Oeuvres complètes de Voltaire, Mélanges IV (1763-1766), edición de Kehl [versión electrónica: http:// www.voltaire-integral.com/Html/25/01_Table_Tolerance.html]. 
indiferentismo religioso, como signo de la tolerancia. Siguiendo un estilo que le es querido, el autor no presenta una doctrina sistemática; para obtenerla hay que hacer un esfuerzo de inducción que no siempre resulta fácil. Los principios más profundos están implícitos en espacios discontinuos, insinuados en figuras retóricas, cifrados en los pliegues de la ironía o subyacentes a los hechos históricos unilateralmente seleccionados.

Con ocasión de la muerte de Jean Calas (1753) y bajo un hilo argumentativo que se pretende histórico ${ }^{43}$, Voltaire retrata en pocas líneas una suerte de trayectoria de la tolerancia y de su contrario, conduciendo al lector a la conclusión-diseminada a trazos en diversos capítulos- de que la gran causa de la intolerancia en el mundo es el dogmatismo religioso, esto es, el contenido objetivo de la Revelación mosaica y cristiana.

El capítulo $22^{\circ}$ dedicado a la tolérance universelle representa una buena síntesis del pensamiento volteriano. Propone una tolerancia entre todas las religiones basada en la imposibilidad de que el hombre, "pequeño como una hormiga”,pueda tener acceso a la verdad divina: "Ce petit globe, qui n'est qu'un point, roule dans lespace, ainsi que tant dautres globes; nous sommes perdus dans cette immensité. L'homme, haut denviron cinq pieds, est assurément peu de chose dans la création. Un de ces êtres imperceptibles dit à quelques-uns de ses voisins, dans l Arabie ou dans la Cafrerie: "Ecoutez-moi, car le Dieu de tous ces mondes m'a éclairé: il y a neuf cents millions de petites fourmis comme nous sur la terre, mais il n'y a que ma fourmilière qui soit chère à Dieu; toutes les autres lui sont en horreur de toute éternité; elle sera seule heureuse, et toutes les autres seront éternellement infortunées. Ils m' arrêteraient alors, et me demanderaient quel est le fou qui a dit cette sottise. Je serais obligé de leur répondre: "C est vous-mêmes"

La figura de la hormiga frente a un mundo desconocido de espacios infinitos dibuja de una manera inmejorable la posición del ser humano ante la pretensión de veracidad de la religión positiva. Nos encontramos ante la negación de la verdad divina como verdad revelada y salvífica, tal como magisterialmente la enseña la Iglesia: "O sectateurs d' un Dieu clément! si vous aviez un coeur cruel; si, en adorant celui dont toute la loi consistait en ces paroles: "Aimez Dieu et votre prochain", vous aviez surchargé cette loi pure et sainte de sophismes et de disputes incompréhensibles; si vous aviez allumé la discorde, tantôt pour un mot nouveau, tantôt pour une seule

${ }^{43}$ Voltaire hace un resumen de los hechos en el capítulo $1^{\circ}$ : "Histoire abrégée de la mort de Jean Calas" y en el "Article nouvellement ajouté dans lequel on rend compte du dernier arrêt rendu en faveur de la famille Calas". Nuestro filósofo mezcla indiscriminadamente los hechos con sus juicios de valor, lo que impide al lector conocer los elementos fácticos en su puridad.

${ }^{44}$ Ibíd., cap. $22^{\circ}$ : "Este pequeño globo, que no es más que un punto, rueda en el espacio, lo mismo que tantos otros globos; estamos perdidos en esa inmensidad. El hombre, de una estatura aproximada de cinco pies, es seguramente poca cosa en la creación. Uno de esos seres imperceptibles dice a algunos de sus vecinos: 'Escuchadme, porque el Dios de todos esos mundos me ha iluminado: hay novecientos millones de pequeñas hormigas como nosotros en la tierra, pero sólo mi hormiguero es grato a Dios; todos los otros le son odiosos desde la eternidad; únicamente mi hormiguero será feliz, todos los demás serán eternamente desgraciados'. Entonces me interrumpirían y me preguntarían quién es el loco que ha dicho semejante tontería. Me vería obligado a responderles: Vosotros mismos". 
lettre de l alphabet; si vous aviez attaché des peines éternelles à lomission de quelques paroles, de quelques cérémonies que d autres peuples ne pouvaient connaître" 45 .

La cita revela que para Voltaire la discordancia dogmática entre la Iglesia y la variedad de confesiones protestantes, y más ampliamente entre las diversas religiones constituidas, no es más que un problema de puntos y comas, o de gramática o de jerga entre academias de distintos dialectos. La razón es clara. Como no existe la verdad divina, las diferencias religiosas son algo baladí, similar a "les petites différences entre les vêtements qui couvrent nos débiles corps", a "nos langages insuffisants", "nos usages ridicules", "nos lois imparfaites", "nos opinions insensées", "petites nuances qui distinguent les atomes appelés hommes" 46 . Esta idea de la inanidad de las verdades de fe es precisada por el Dictionnaire Philosophique: "Aurait-il été possible à lesprit humain [...] admettre une religion [...] qui fût moins mauvaise que toutes les autres religions de l univers ensemble? et quelle serait cette religion? Celle qui admettrait très peu de dogmes inventés par la démence orgueilleuse,éternels sujets de dispute; celle qui enseignerait une morale pure, sur laquelle on ne disputât jamais? Celle qui ne ferait point consister lessence du culte dans de vaines cérémonies [...]? celle qui tolérerait toutes les autres, et qui, méritant ainsi la bienveillance de toutes, serait seule capable de faire du genre humain un peuple de frères? Celle qui aurait des cérémonies augustes dont le vulgaire serait frappé, sans avoir des mystères qui pourraient révolter les sages et irriter les incrédules? Une grande partie de cette religion est déjà dans le coeur de plusieurs princes, et elle sera dominante" ${ }^{47}$.

En el texto queda patente la relación que existe entre el escepticismo religioso y la tolerancia, y la voluntad de influencia política para que esto se traduzca a hechos en los pueblos cristianos. La verdad divina, en los tres elementos constitutivos de la religión -verdades dogmáticas que hay que creer, moral religiosa que hay que practicar y culto a Dios-son inventos de la démence orgueilleuse. "Orgullosa" porque nada justifica la asunción de que la propia creencia es una verdad y no una opinión. Demencia, porque es locura creer que existe algo que la razón no pueda comprender a través de la constatación de los sentidos. "Demencia” porque la fe convierte esa irracionalidad en dogma, que tiene como consecuencia necesaria el

${ }^{45}$ Ibíd.: “¡Oh sectarios de un Dios clemente! [...] 'Amad a Dios y a vuestro prójimo’ [...] (Habéis) recargado esta ley pura y santa con sofismas y disputas incomprensibles; [...] (habéis) encendido la discordia, unas veces por una palabra nueva, otras por una sola letra del alfabeto; [...] (Habéis) atribuido penas eternas a la omisión de algunas palabras, de algunas ceremonias que otros pueblos no podrían conocer”.

${ }^{46}$ Ibíd, cap. $23^{\circ}$.

${ }^{47}$ ¿Sería posible al espíritu humano [...] admitir una religión [...] que sea menos mala que todas las otras religiones del universo juntas? ¿Y cuál sería esa religión? La que admitiera muy pocos dogmas inventados por la orgullosa demencia, motivos eternos de disputas; la que enseñase una moral pura sobre la que no se disputase jamás. La que no hiciera consistir la esencia del culto en vanas ceremonias [...]. La que tolerara a todas las demás y que mereciendo así el afecto de todas fuera la única capaz de hacer del género humano un pueblo de hermanos. La que tuviera ceremonias augustas que hiciesen impresión en el vulgo, sin tener misterios que pudiesen sublevar a los sabios e irritar a los incrédulos. Gran parte de esta religión está grabada hoy en el corazón de algunos príncipes, y llegará a ser la dominante": VOLTAIRE, s.v. "Religion" del Dictionnaire philosophique (1764, Paris, Louis Moland chez Garnier, 1870-1880) [versión digital en: [ http://www.voltaire-integral.com/Html/20/religion.htm]. 
enfrentamiento, sea por la vía de las ideas, sea por la vía de los hechos, e impide el advenimiento de la fraternidad universal en torno a los sentimientos morales comunes.

La pretensión de veracidad de la fe, la afirmación de una verdad religiosa es "la fureur qu' inspirent lesprit dogmatique" 48 , y, por tanto, es lo que lleva a los hombres a la intolerancia: "Le droit de lintolérance est donc absurde et barbare: c'est le droit des tigres, et il est bien horrible, car les tigres ne déchirent que pour manger, et nous nous sommes exterminés pour des paragraphes" ${ }^{\prime \prime}$.

Los párrafos, esto es, las verdades objetivas, transmutan la naturaleza racional convirtiendo a los hombres en tigres que matan por matar. Desde esta óptica, Voltaire llama "fanatisme" no sólo a tal o cual exceso de las ideas religiosas arrastradas por las pasiones humanas, sino a la afirmación especulativa de que existe una verdad divina, con las tres cualidades que ya conocemos. La intolerancia práctica deriva axiomáticamente de la intolerancia dogmática, "fanatismo" especulativo y práctico llamado a desaparecer por obra del criticismo de las luces: "La philosophie, la seule philosophie, cette soeur de la religion, a désarmé des mains que la superstition avait si longtemps ensanglantées; et l esprit humain, au réveil de son ivresse, s'est étonné des excès où l avait emporté le fanatisme" ${ }^{50}$.

Los conceptos de "fanatismo" y de "superstición" recorren todos los escritos de Voltaire ${ }^{11}$, oponiéndolos a los de "razón” y "las luces". Ambos se convierten

\footnotetext{
${ }^{48}$ Voltaire, Traité sur la Tolérance, cit, cap. $4^{\circ}$ : "El furor que inspira el espíritu dogmático".

${ }^{49}$ Ibíd., cap. $6^{\circ}:$ "El derecho de la intolerancia es pues absurdo y bárbaro: es el derecho de los tigres, y es mucho más horrible, porque los tigres sólo matan para comer, y nosotros nos hemos exterminado por unos párrafos".

${ }^{50}$ Ibíd., cap. $4^{\circ}$ : "La filosofía, la sola filosofía, esa hermana de la religión, ha desarmado manos que la superstición había ensangrentado tanto tiempo; y la mente humana, al despertar de su ebriedad, se ha asombrado de los excesos a que la había arrastrado el fanatismo".

${ }^{51}$ El Diccionario filosófico se hace cargo de la descripción de estos conceptos, dejando su sentido definitivo en la implicitud. La voz "Fanatismo" así precisa el concepto: "es el efecto de una conciencia falsa, que sujeta la religión a los caprichos de la fantasía y al desconcierto de las pasiones" y agrega irónicamente que los fanáticos no siempre pelean los "combates del señor", que "no siempre asesinan reyes y príncipes; algunos de ellos son tigres, pero la mayoría son zorros". Voltaire, Diccionario filosofico (Madrid, Temas de Hoy, 1995), II, pp. 87 y 93. Está entredicho que el capricho de la fantasía es el dogma religioso. La alusión al "desconcierto de las pasiones" es notable, dado que una de las grandes quejas de los philosophes contra el cristianismo es el ascetismo moral. La referencia a la conciencia falsa anuncia que a ella no se aplica la libertad de conciencia moderna. La s.v. "Superstición" es más críptica. Voltaire no da ningún tipo de definición, sino que describe los modelos de conducta que calzan con el culto católico: creencia en los milagros, las procesiones, devoción a los santos, etc. En este cuadro, establece el vínculo de unión entre el fanático -el teórico del dogma- y el supersticioso -el que lo practica-: "el supersticioso es al bribón lo que el esclavo es al tirano. El supersticioso se deja gobernar por el fanático y acaba por serlo también. La superstición nació en el paganismo, la adoptó el judaísmo e infectó la Iglesia cristiana de los primitivos tiempos. [...]. Hoy la mitad (protestante) de Europa cree que la otra mitad (la católica) fue durante mucho tiempo supersticiosa y lo es todavía”. Ibíd., p. 560.
} 
en hipóstasis paradigmáticas: los primeros de la Iglesia Católica, los segundos de los philosophes ${ }^{52}$.

Por nimiedades ridículas, los fanáticos imponen la intolerancia en el mundo o inician disputas que sólo atraen desgracias: "Moins de dogmes, moins de disputes; et moins de disputes, moins de malheurs: si cela n' est pas vrai, $j$ ai tort" ${ }^{3}$

Esas desgracias -Voltaire es reiterativo al extremo- son resultado del dogma cristiano, responsable de la sangre corrida en el mundo: "On sait assez ce qu' il en a coûté depuis que les chrétiens disputent sur le dogme: le sang a coulé,soit sur les échafauds, soit dans les batailles, dès le IV e siècle jusqu'à nos jours" ${ }^{54}$.

\section{3) El puño de plomo bajo el guante de seda.}

Pero hay que precisar aún más. Es el catolicismo, como paradigma de la intolerancia dogmática, el que ha hecho correr sangre en la historia. No existirá tolerancia en la tierra mientras se siga afirmando la verdad divina como lo hace la Iglesia. Si en el siglo XVI emergieron las guerras religiosas, la responsabilidad provino de la Iglesia, no de la Reforma, pues aquella mantuvo su intransigencia doctrinaria, mientras éstos levantaron la bandera del "desarrollo del espíritu humano" 55 .

De ahí que de un modo matemático los países no influenciados por la Iglesia, como las naciones protestantes -Voltaire se empeña en afirmarlo- sean un modelo de tolerancia. En Holanda o Inglaterra donde el culto católico está prohibido sólo ve libertad ${ }^{56}$. Las víctimas en Irlanda -la población católica- son en realidad los perseguidores, que felizmente han sido diezmados ${ }^{57}$.

Voltaire no se detiene ante la torsión histórica. Utiliza la misma parcialidad que puede verse en Bayle, pero con aplicaciones más universales. En las naciones no cristianas -India, Persia, China, Japón, etc., en la particular opinión de nuestro filósofo, conviven de un modo idílico todas las religiones en paz y tolerancia.

${ }^{52}$ Un ejemplo, entre muchos. En el Traité sur la Tolérance, cit, cap. $1^{\circ}$, nuestro filósofo afirma que "la raison l'emporte à Paris sur le fanatisme, quelque grand qu' il puisse être, au lieu qu'en province le fanatisme l'emporte presque toujours sur la raison”. En París, el círculo de los philosophes tenía seguidores en un amplio sector de aristócratas, eclesiásticos y burgueses adinerados, incluso en la Corte del Rey. Pero en las zonas rurales, fuertemente influidas por la vida católica tradicional, esa influencia era minúscula en las masas. Esto no le impide a Voltaire considerar el sentido utilitario que la religión tiene para el vulgo, mientras no sean iluminados por los philosophes. A ello dedica el cap. $20^{\circ}$ del Traité sur la Tolérance que titula "S'il est utile d'entretenir le peuple dans la superstition". Ahí afirma que "telle est la faiblesse du genre humain, et telle est sa perversité, qu'il vaut mieux sans doute pour lui d'être subjugué par toutes les superstitions possibles, pourvu qu'elles ne soient point meurtrières, que de vivre sans religión. L' homme a toujours eu besoin d'un frein [...]".

${ }^{53}$ Ibíd., cap. $21^{\circ}$ : "Cuanto menos dogmas, menos disputas y cuanto menos disputas, menos desgracias".

${ }^{54}$ Ibíd., cap. $2^{\circ}$ : "De sobra se sabe todo lo que ha costado desde que los cristianos disputan sobre el dogma: ha corrido la sangre, ya sea en los patíbulos ya en los campos de batalla, desde el siglo IV hasta nuestros días".

${ }^{55}$ Ibíd., cap. $3^{\circ}$.

${ }^{56}$ Ibíd., cap. $4^{\circ}$.

${ }^{57}$ Ibíd.: La falsificación histórica es notoria: "Irlanda, poblada y enriquecida, ya no verá a sus ciudadanos católicos sacrificar a Dios, durante dos meses, a sus ciudadanos protestantes”. 
Son las misiones católicas las que han intentado llevarles la intolerancia con sus objetivos evangelizadores. Por ello, han sido justamente perseguidos en Japón o China $^{58}$. En una sola palabra, y apurando la lógica volteriana, sólo el catolicismo puede y debe ser plenamente intolerante (es una cuestión de principios) porque sólo él afirma con autoridad magisterial poseer la verdad religiosa.

En este esquema, el filósofo de Ferney rehace la historia del paganismo, al que le atribuye intenciones siempre benéficas y humanitarias, y deshace la del cristianismo, al que le imputa persecuciones y violencias permanentes. La lógica exclusiva de las suposiciones, que adopta como hechos históricos, mueve todo su relato. Grecia y Roma, y en general todos los pueblos de la antigüedad, habrían sido pueblos tolerantes y humanitarios porque no eran cristianos, no pretendían atribuirse una verdad religiosa ${ }^{59}$. Las persecuciones de Roma contra el cristianismo no se debieron a la intolerancia pagana -pues está pre-definido que el paganismo es tolerante, porque no es dogmático- sino al espíritu fanático de la fe cristiana, cuando no a exageraciones o mentiras históricas inventadas por sus seguidores ${ }^{60}$.

Llegado a este punto, Voltaire vincula la tolerancia dogmática con la libertad de conciencia. La primera es condición sine qua non para la segunda. Por el contrario, la intolerancia dogmática tiene como resultado la opresión de la libertad de conciencia, sea por una vía íntima (a través de la imposición magisterial de una verdad divina obligatoria), sea por una vía social (a través de las diversas formas jurídicas, políticas y fácticas que consagran una religión de Estado).

Este presupuesto se ve confirmado por la historia. Todos los pueblos que no han asumido una verdad divina, en el sentido fuerte de la palabra, han sido pueblos tolerantes y han respetado la libertad de conciencia. El ejemplo se encuentra en toda la historia antigua: los pueblos paganos, reitera Voltaire, respetaron universalmente la libertad de conciencia: "Les peuples dont l histoire nous a donné quelques faibles connaissances ont tous regardé leurs différentes religions comme des noeuds qui les unissaient tous ensemble: c'était une association du genre humain [...] Un étranger arrivait-il dans une ville, il commençait par adorer les dieux du pays. On ne manquait jamais de vénérer les dieux même de ses ennemis [...] Je peux me tromper; mais il me paraît que de tous les anciens peuples policés, aucun n'a gêné la liberté de penser. Tous avaient une religion; mais il me semble qu'ils en usaient avec les hommes comme avec leurs dieux: ils reconnaissaient tous un dieu suprême, mais ils

${ }^{58}$ Ibíd., cap. $4^{\text {o }}$ : "El gran emperador Yung-Chêng, el más sabio y el más magnánimo que tal vez haya tenido China, ha expulsado a los jesuitas; pero esto no lo hizo por ser intolerante; fue, al contrario, porque lo eran los jesuitas".

${ }^{59}$ Ibíd., cap. $7^{\circ}$ : "Si l'intolérance a été connue des Grecs"; y cap. $8^{\circ}$ : "Si les Romains ont été tolérants".

${ }^{60}$ Voltaire se asoma a las dos alternativas: los cristianos fueron los responsables de la persecución que contra ellos inició el Imperio Romano porque eran intolerantes y además tales persecuciones han resultado exageradas por las propias víctimas, quienes han mentido. En este plano, la historia del heroísmo de los mártires cristianos se le figura ridícula e inverosímil. Ibíd, cap. $9^{\circ}$ "Des Martyrs" y cap. 10 "Du danger des fausses légendes et de la persécution". Es una técnica reiterada de Voltaire el convertir sus suposiciones en hechos históricos, con fórmulas como "no es verosímil que esto haya ocurrido (luego no ocurrió) o se debe suponer esto (entonces realmente sucedió)". 
lui associaient une quantité prodigieuse de divinités inférieures; ils n'avaient qu'un culte,mais ils permettaient une foule de systèmes particuliers" ${ }^{61}$.

Es notable cómo la cita resalta la tolerancia específicamente dogmática como condición de la libertad de pensamiento en materia religiosa, lo que confirma sobremanera nuestra tesis : "Chez les anciens Romains, depuis Romulus jusqu' aux temps où les chrétiens disputèrent avec les prêtres de lempire, vous ne voyez pas un seul homme persécuté pour ses sentiments" 62.

La intolerancia (primero dogmática, después práctica) del cristianismo no nació, sin embargo, con Cristo. En su Dictionnaire philosophique Voltaire puntualiza que Jesús no quiso enseñar una religión nueva, sino una moral humanitaria común a todas las religiones y éticas. Son los clérigos lo que crearon el dogma con sus concilios y símbolos de fe, y desde entonces, a causa de disputas metafísicas que nadie entiende, se degüellan unos a otros ${ }^{63}$.

Desde un punto de vista histórico, las guerras religiosas, agrega el Traité sur la Tolérance, constituyen el clímax de los frutos prácticos de la intolerancia dogmática. Pero a partir de la Paz de Westfalia se han abierto las puertas a la libertad de conciencia $^{64}$, que avanza en la medida que se asumen que las diferencias doctrinarias

${ }^{61}$ Ibíd., cap. $7^{\circ}$ : "Los pueblos de los que la historia nos ha dejado algunos débiles conocimientos han considerado, todos, sus diferentes religiones como nudos que los unían: era una asociación, tanto entre los dioses como entre los hombres [...]. Cuando un extranjero llegaba a una ciudad, empezaba por adorar a los dioses del país. Jamás se dejó de venerar a los dioses, incluso a los de los enemigos [...]. Tal vez me equivoque; pero me parece que de todos los antiguos pueblos civilizados, ninguno ha puesto trabas a la libertad de pensar. Todos tenían una religión; pero me parece que la usaban con los hombres del mismo modo que con sus dioses".

${ }^{62}$ Ibíd., $8^{\circ}$ : "Entre los antiguos Romanos, desde Rómulo hasta los tiempos en que los cristianos se disputaron con los sacerdotes del imperio, no veréis un solo hombre perseguido por sus sentimientos".

${ }^{63}$ "Il me transporta dans un désert tout couvert d'ossements entassés [...]. Ceux-ci, dit-il, sont les vingt-trois mille Juifs qui dansèrent devant un veau d'or, avec les vingt-quatre mille qui furent tués sur des filles madianites. Le nombre des massacrés pour des délits ou des méprises pareilles se monte à près de trois cent mille. I Aux allées suivantes sont les charniers des chrétiens égorgés les uns par les autres pour des disputes métaphysiques. Ils sont divisés ce plusieurs monceaux de quatre siècles chacun. Un seul aurait monté jusqu'au ciel; il a fallu les partager. -Quoi m'écriai-je, des frères ont ainsi traité leurs frères, et j'ai le malheur d' être de cette confrérie. -Voici, dit l'esprit, les douze millions d'Américains tués dans leur patrie, parce qu' ils n'avaient pas été baptisés. -Eh, mon Dieu! que ne laissiez-vous ces ossements affreux se dessécher dans l' hémisphère où leurs corps naquirent, et où ils furent livrés à tant de trépas différents? Pourquoi réunir ici tous ces monuments abominables de la barbarie et du fanatisme? - Pour t' instruire. - Puisque tu veux m' instruire, dis-je au génie, apprends-moi s'il y a eu d'autres peuples que les chrétiens et les juifs à qui le zèle et la religion malheureusement tournée en fanatisme aient inspiré tant de cruautés horribles. -Oui, me dit-il, les mahométans se sont souillés des mêmes inhumanités, mais rarement; et lorsqu'on leur a demandé amman, miséricorde, et qu'on leur a offert le tribut, ils ont pardonné. Pour les autres nations, il n'y en a aucune depuis l'existence du monde qui ait jamais fait une guerre purement de religión". Voltaire, s.v. "Religión” del Dictionnaire philosophique, cit. En el mismo sentido, el Traité sur la Tolérance, cap. $15^{\circ}$, describe las disputas religiosas como "una enfermedad epidémica", una "peste" irracional.

${ }^{64}$ Ibíd., cap. 5: "Alemania sería un desierto cubierto por los huesos de los católicos, de los 
entre las religiones son errores inherentes a nuestra naturaleza y que esos errores no deben ser causantes de nuestras calamidades ${ }^{65}$.

Esto le permite a nuestro filósofo trazar la figura de una libertad de conciencia desvinculada de toda instancia trascendente. Frente al principio de que "todas las religiones son obra de los hombres y que sólo la Iglesia católica, apostólica y romana es obra de Dios, contrapone la libertad del ciudadano de no creer más que a su razón y pensar lo que esta razón, acertada o equivocada, le dicte" "66. ¿Y que debe creer la razón? Lo que ella quiera, siempre que se sitúe en la perspectiva de la inmanentización de la conciencia como término del proceso de liquidación de la verdad religiosa. Como muestran los capítulos $16^{\circ}$ ("Dialogue entre un mourant et un homme qui se porte bien") y $23^{\circ}$ ("Prière à Dieu") del Traité sur la Tolérance, la trascendencia de la verdad divina constituye una tiranía para la libertad de conciencia, que hay que repudiar para que ésta se expanda ${ }^{67}$. Al respecto, el epigrama de Voltaire es inequívoco: "Qu'ils aient en horreur la tyrannie exercée sur les âmes,comme ils ont en exécration le brigandage qui ravit par la force le fruit du travail et de lindustrie paisible" ${ }^{68}$.

En la voz "liberté de penser" del Dictionnaire philosophique, Voltaire muestra la necesidad de liberarse de esta tiranía para tener libertad de conciencia, no sólo en el ámbito religioso, sino también en el moral e intelectual. La tesis es que sólo quien se despoja de la tutela católica -por obra de las luces- es libre para pensar. Para tales efectos, se simula un diálogo entre Lord Boldmind, oficial inglés, y el conde Medroso, amigo de la Inquisición. El Imperio español y la Iglesia son pintados con los más negros colores, como responsables de la imposición del yugo religioso al pueblo, mientras en las naciones protestantes, como Inglaterra y Holanda, reina la tolerancia y la libertad de conciencia. "-Boldmind: vous étiez cent fois plus heureux sous le joug des Maures, qui vous laissaient croupir librement dans toutes vos superstitions, et qui, tout vainqueurs qu' ils étaient, ne s'arrogeaient pas le droit inoui de tenir les âmes dans les fers. - Medroso: Que voulez-vous? il ne nous est permis ni d'écrire, ni de parlcr, ni même de penser [...] mais on m' a dit que la religion catholique, basque et romaine, est perdue, si on se met à penser. —Boldmind: Il y a cent religions sur la terre, qui toutes vous damnent si vous croyez à vos dogmes, quelles appellent absurdes et impies; examinez donc ces dogmes [...]. Il ne tient qu'à vous d'apprendre à penser; [...] il est honteux de mettre son âme entre les mains de ceux à qui vous ne confieriez pas votre argent [...]. Ce sont ces tyrans des esprits qui ont causé une partie

evangelistas, de los reformados, de los anabaptistas, que se habrían degollado unos a otros, si la paz de Westfalia no hubiese procurado, por fin, la libertad de conciencia”.

${ }^{65}$ Ibíd., cap. $23^{\circ}$.

${ }^{66}$ Ibíd., cap. $11^{\circ}$.

${ }^{67}$ En el Traité sur la Tolérance se resalta el rechazo a la verdad divina como revelada y salvífica. El moribundo es una víctima de la violación de conciencia operada por un hombre religioso que le impele a profesar en términos que resultan satíricos el dogma religioso como condición de su salvación. Voltaire, Traité sur la Tolérance, cit., cap. 16, Dialogue entre un mourant et un homme qui se porte bien En Ibíd., cap. $23^{\circ}$, se subraya la impostura del concepto de verdad divina como infalible.

${ }^{68}$ Ibíd., cap. $33^{\circ}$, p. 33. “¿Que odien [los hombres] la tiranía ejercida sobre las almas como odian el latrocinio que arrebata a la fuerza el fruto del trabajo y de la industria pacífica!” 
des malheurs du monde [...]. Vous êtes tranquilles, mais vous n'êtes pas heureux; c'est la tranquillité des galériens, qui rament en cadence et en silence" ${ }^{69}$.

Ya nos hemos referido a las razones filosóficas que tiene Voltaire para hipostasiar la intolerancia en la Iglesia católica. Acá quisiéramos destacar cómo la inmanencia de la conciencia se ha expandido desde el campo religioso al moral e intelectual, en cuyo espacio rige ahora una ley natural reducida a los sentimientos comunes de humanidad ${ }^{70}$, representados, por ejemplo, en el principio de reciprocidad que alimenta la tolerancia religiosa: "Le droit humain ne peut être fondé en aucun cas que sur ce droit de nature; et le grand principe, le principe universel de Pun et de lautre,est,dans toute la terre: "Ne fais pas ce que tu ne voudrais pas qu'on te fit". Or on ne voit pas comment, suivant ce principe, un homme pourrait dire à un autre: "Crois ce que je crois, et ce que tu ne peux croire, ou tu périras". Cest ce qu'on dit en Portugal, en Espagne, à Goa"

Sin verdad divina, sin ley natural objetiva, la conciencia queda carente de criterios ciertos. ¿Es ésta la meta de Voltaire? ¿Es éste el nuevo estatus antropológico sobre el que se proclama la libertad de conciencia y de religión ilustrada? Es lo que confirma el Diccionario filosófico donde la conciencia aparece desvinculada de cualquier padrón objetivo y trascendente de moralidad: "Il résulte de tout cela que nous n'avons point d autre conscience que celle qui nous est inspirée par le temps, par lexemple, par notre tempérament, par nos réflexions. L'homme n'est né avec aucun principe, mais avec la faculté de les recevoir tous"72.

${ }^{69}$ Voltaire, s.v. "Liberté de penser" del Dictionnaire philosophique, cit.: "--Boldmind: erais cien veces más dichosos cuándo sufríais el yugo de los moros, que os dejaban tener todas las supersticiones que queríais, y que a pesar de ser los vencedores no se arrogaban el derecho de amarrar el corazón con cadenas. --Medroso: solo os puedo decir que no se nos permite escribir, hablar ni pensar siquiera [...]. Me han asegurado que la religión católica y romana se pierde si nos dejan pensar. --Boldmind: Hay muchas religiones en el mundo, y todas os condenan si creéis en vuestros dogmas, que los tienen por absurdos y por impíos; examinad pues vuestros dogmas [...]. De vos depende aprender a pensar; atreveos a pensar que es vergonzoso poner el alma en las manos de aquellos a quienes no confiarías el dinero [...]. Los tiranos del pensamiento son los que han causado gran parte de las desgracias del mundo [...]. Gozáis de la tranquilidad de los galeotes que mueven los remos cadenciosamente y callando".

${ }^{70}$ En la época del Dictionnaire philosophique, Voltaire ya ha radicalizado sus posturas filosóficas hasta negar la inmortalidad del alma y el libre albedrío, adhiriendo a posiciones deterministas. En su XIII Carta Filosófica declara que es imposible saber si el alma es inmortal. "Hace mucho tiempo que los hombres discuten sobre la naturaleza y la inmortalidad del alma humana. Es imposible demostrar la inmortalidad del alma, pues aún discutimos sobre la naturaleza y hay que conocer a fondo un ser creado para decir si es o no inmortal". VOLTAIRE, Cartas filosóficas, edición completa de la Biblioteca digital Ciudad Seva en: http://www.ciudadseva. com/textos/otros/voltaire/carfilo/indice.htm. La Carta 13a en: http://www.ciu dadseva.com/ textos/otros/voltaire/carfilo/13.htm.

${ }^{71}$ Voltaire, Traité sur la Tolérance, cit., cap. $6^{\circ}$ : "El derecho humano no puede estar basado en ningún caso más que sobre este derecho natural; y el gran principio, el principio universal de uno y otro es, en toda la tierra: 'No hagas lo que no quisieras que te hagan'. No se comprende, por lo tanto, según tal principio, que un hombre pueda decir a otro: 'Cree lo que yo creo y lo que no puedes creer, o perecerás'. Esto es lo que se dice en Portugal, en España, en Goa".

${ }^{72}$ Voltaire, S.v. "Consciencer" del Dictionnaire philosophique, cit.: "Nuestra conciencia 
De este modo tocamos ya los dos extremos del pensamiento volteriano en la materia que investigamos. Por una parte, podemos dar por sentado el escepticismo religioso y moral, de corte no sólo epistemológico, sino también metafísico, en el que se rechaza de plano la existencia de una verdad divina. Por otra parte, la libertad de conciencia, que pende de tal negación, postula la tolerancia en materia religiosa a fin de expandir la desligación del sujeto humano con Dios y la reafirmación de su inmanencia y subjetividad. Tal dilatación es el punto de encuentro entre ambos extremos.

Lo anterior explica por qué la tolerancia volteriana esté concebida para unos y no para otros. Lo que no expande la libertad de conciencia moderna no merece tolerancia. Católicos primeros, después judíos y protestantes, son víctimas de la intolerancia volteriana, por representar, en diversos grados, el principio trascendente de lo religioso revelado.

El capítulo $18^{\circ}$ ("Seuls cas où P intolérance est de droit humain") del Traité sur la Tolérance está dedicado a esta cuestión, que es presentada a veces, en términos equívocos, como la problemática de si los intolerantes merecen tolerancia.

Los términos son arteros y suponen una cierta deshonestidad intelectual en el planteamiento y una ambigüedad engañosa en la formulación. En efecto. ¿o pende esta fórmula de la identificación previa de quiénes son los intolerantes? Pero ¿quién puede definir con seguridad y precisión el complejo límite entre lo tolerable y lo intolerable? ¿El que usa la fórmula?

El filósofo de Ferney cayó en este mecanismo engañoso al imputar intolerancia a quienes no pensaban como él, en un terreno que para su tiempo era el más decisivo cual era el religioso. Ello lo llevó a la inexcusable inconsecuencia de erigir una pseudo inquisición de las ideas en nombre de la libertad y de la tolerancia, cuyos pontífices eran los philosophes. Fue la acusación que ya en la época hizo Alessandro Verri, con admirable honestidad intelectual, desde el propio círculo de la Ilustración ${ }^{73}$.

En este cuadro, no es de extrañar que Voltaire defienda, sin temor a contradecirse, que hay amplísimos crímenes de opinión -el dogmatismo religioso- y que esos crímenes no pueden ni deben ser tolerados. De ahí su peligroso epígrafe de que hay que merecer la tolerancia para ser tolerado: "Pour qu'un gouvernement ne soit pas en droit de punir les erreurs des hommes, il est nécessaire que ces erreurs ne soient pas des crimes; elles ne sont des crimes que quand elles troublent la société: elles

la inspira la época, el ejemplo, el temperamento y la reflexión. El hombre nació sin ningún principio, pero con la facultad de recibir todos los principios”. Voltaire, s.v. Conciencia del Diccionario Filosófico, cit., I, p. 460. En loc. cit. el editor apunta acertadamente que "al negar las ideas innatas y la moral religiosa porque es particularista e intolerante, los ilustrados buscan los fundamentos universales de la moralidad no en los contenidos de la mente sino en sus capacidades, es decir, en la razón y la sensibilidad (cuyo ejercicio va siempre unido en los ideales del siglo XVIII), lo que no resulta muy convincente pues deja sin explicar por qué se exigiría a todos los hombres que consideraran estas capacidades más nobles, reprimiendo otras como la agresividad, por ejemplo”.

73 "Alessandro Verri hablaba de esos filósofos franceses que, si hubieran podido, habrían instituido la Inquisición contra todos los que no eran de sus opiniones" Paul Hazard, El Pensamiento europeo, cit. (n. 1), p. 363. 
troublent cette société, dès qu'elles inspirent le fanatisme; il faut donc que les hommes commencent par n'être pas fanatiques pour mériter la tolérance" 74 .

El enunciado de la última frase es elocuente. La tolerancia no es un derecho que se tenga por el simple hecho de pensar distinto. Hay que merecerla. Y no la merecen quienes son fanatiques, amplio género en el que se engloba a los adversarios de la Ilustración, sea en el pensamiento, sea en el modo de vida. En este último cuadro caen las órdenes monásticas de la Iglesia, como los dominicos, jesuitas, etc., responsables de difundir "maximes coupables". A éstos, que como todos los sacerdotes, son esclavos de la fe hay que forzarlos a ser libres: "[...] on ne peut s' empêcher de dissoudre leur compagnie, et d' abolir les jésuites pour en faire des citoyens: ce qui au fond est un mal imaginaire, et un bien réel pour eux, car où est le mal de porter un habit court au lieu d' une soutane, et de être libre au lieu dêtre esclave? On réforme à la paix des régiments entiers, qui ne se plaignent pas: pourquoi les jésuites poussent-ils de si hauts cris quand on les réforme pour avoir la paix?"75.

De la intolerancia de Voltaire no se salvan ni los protestantes ni los judíos. De los primeros -luteranos y calvinistas- asegura que son lobos que hay que perseguir si mantienen su dogmatismo religioso ${ }^{76}$. De los segundos, objeto de desprecios e injurias a lo largo de sus escritos, dice con ironía: "Les Juifs sembleraient avoir plus de droit que personne de nous voler et de nous tuer: car bien qu'ily ait cent exemples de tolérance dans $I$ Ancien Testament,cependant il y a aussi quelques exemples et quelques lois de rigueur. Dieu leur a ordonné quelquefois de tuer les idolâtres, et de ne réserver que les filles nubiles: ils nous regardent comme idolatres, et, quoique nous les tolérions aujourd hui, ils pourraient bien, s'ils étaient les maîtres, ne laisser au monde que nos filles [...]. Si les Juifs raisonnaient ainsi aujourd hui, il est clair qu' il n'y aurait d' autre réponse à leur faire que de les mettre aux galères"77.

Detrás de la tolerancia y de la libertad de conciencia y de religión modernas, tal como las concibe Voltaire, se esconde la mano de plomo de la intolerancia contra el cristianismo y el judaísmo mosaico, y en general, contra toda religión positiva. Sólo cuando sean reducidas a meras opiniones y creencias privadas, sumamente domésticas y subjetivas, cuando sean expulsadas del espacio público,

${ }^{74}$ Voltaire, Traité sur la Tolérance, cit., cap. $18^{\circ}$ : "Para que un gobierno no tenga derecho a castigar los errores de los hombres, es necesario que tales errores no sean crímenes: sólo son crímenes cuando perturban la sociedad: perturban la sociedad si inspiran fanatismo; es preciso, por lo tanto, que los hombres empiecen por no ser fanáticos para merecer la tolerancia”.

${ }^{75}$ Ibíd.: "[...] No hay más remedio que disolver su compañía y abolir a los jesuitas para convertirlos en ciudadanos; lo cual, en el fondo, es un mal imaginario y un bien real para ellos, porque ¿dónde está el mal de llevar chupa en lugar de sotana, de ser libre en lugar de esclavo? Se licencia en tiempos de paz a regimientos enteros, que no se quejan de ello: ¿por qué los jesuitas lanzan tales gritos cuando se los disuelve para tener paz?”.

${ }^{76}$ Ibíd.: "On en dira autant des luthériens et des calvinistes. Ils auront beau dire: Nous suivons les mouvements de notre conscience, il vaut mieux obéir à Dieu quaux hommes; nous sommes le vrai troupeau, nous devons exterminer les loups; il est évident qu'alors ils sont loups eux-mêmes [...]"

${ }^{77}$ Ibíd.: "Los judíos parecerían tener más derecho que nadie a robarnos y matarnos [...] Dios les ordenó a veces que matasen a los idólatras, exceptuando únicamente a las jóvenes núbiles: nos consideran idólatras y, aunque los toleramos hoy día, podrían muy bien, si ellos fuesen los amos, no dejar en el mundo más que a nuestras hijas. [...]. Si los judíos razonasen así hoy día, es evidente que no habría otra respuesta que condenarlos a todos a galeras". 
habrán triunfado las libertades modernas. Habrá llegado entonces la hora en que incluso los cristianos o los judíos podrán gozar de tales libertades, siempre que consientan en reducir su fe a una mera opinión íntima, sin derechos políticos ni sociales.

\section{Guyon contra Voltaire.}

Uno de los mejores adversarios de Voltaire, cuyos volúmenes alcanzaron gran difusión no sólo en Francia sino también en España fue Claude-Marie Guyon. Su L'oracle des nouveaux philosophes: Pour servir de suite et d'éclaircissemen aux oeuvres de $M$. de Voltaire ${ }^{78}$ fue recomendada por el papa Clemente XIII ${ }^{79}$ y está escrita contra el espíritu filosófico de la Ilustración, especialmente el deísmo, el indiferentismo religioso y el naturalismo, como se destaca en el Prólogo del traductor español ${ }^{80}$.

El volumen $\mathrm{I}^{81}$ es una extensa refutación del Tratado de la tolerancia, sin excluir citas de otras obras de Voltaire. Reafirma la tesis de que los philosophes han establecido su sistema de pensamiento sobre el naturalismo, lo que supone la negación de la Revelación, la afirmación de una religión natural y el indiferentismo. Guyon denuncia que son estos presupuestos filosóficos y no la consideración hacia el fenómeno religioso ${ }^{82}$ lo que ha llevado a Voltaire a exigir a los Estados católicos la libertad de conciencia y de cultos bajo el velo de la tolerancia práctica ${ }^{83}$. Examina además la utilización estratégica de la libertad de pensamiento para negar la validez social de las doctrinas antropológicas básicas: la inmortalidad del alma, la dependencia de Dios y el libre albedrío ${ }^{84}$.

La obra analiza el método histórico de Voltaire, que considera parcial y arbitrario $^{85}$; coloca en tela de juicio el argumento de los paganos virtuosos y de los cristianos viciosos $^{86}$; examina la consistencia interna de los argumentos contra la divinidad de Cristo y la religión cristiana, así como las negaciones del martirio

${ }^{78}$ Guyon, Claude-Marie, L'oracle des nouveaux philosophes: Pour servir de suite et d'éclaircissemen aux oeuvres de M. de Voltaire, A. Berne, 1760-1765, 2 vols. Seguimos la versión española titulada El Oráculo de los nuevos philosofos, $M$. Voltaire, impugnado y descubierto en sus errores por sus mismas obras, traducida por Fr. Pedro Rodríguez Morzo [el autor figura anónimo], Imprenta de Gabriel Ramírez, Madrid, 1769 (Vol. I) y 1770 (Vol. II).

${ }^{79}$ Ibíd., I, p. V.

${ }^{80}$ Ibíd., p. iii

${ }^{81}$ El volumen II es de naturaleza teológica, y no entra directamente en nuestra consideración. Se impugan las ataques volterianos contra la autenticidad de las Escrituras (pp. 1-73), la inspiración divina en general (pp. 75-101), y en particular en lo que se refiere a la revelación mosaica (pp. 103-277).

${ }^{82}$ Ibíd., Conversa 1 y 2 , pp. 5-16 y 17-70, especialmente en lo que respecta a la oscuridad de una religión natural y de su idea de Dios.

${ }^{83}$ Ibíd., Conv. 3, pp. 71-100.

${ }^{84}$ Ibíd., Conv. 5, pp. 129-170

${ }^{85}$ Ibíd., Conv. 8, pp. 223-258. Sentada las bases del método histórico volteriano, se evalúan algunas de sus obras: El Siglo de Luis XIV (Conv. 9, pp. 259-294); Cándido o del optimismo (Conv. 10, pp. 295-338). Se analiza también el método utilizado en el Compendio del Eclesiastés (Conv. 11, pp. 339-356) y en el Cantar de los cantares (Conv. 12; pp. 357-382).

${ }^{86}$ Ibíd., Conv. 5, pp. 129-170 
de los primeros cristianos ${ }^{87}$; refuta las sátiras volterianas contra el principio de autoridad religiosa, moral y política ${ }^{88}$. Como fondo de cuadro denuncia que lo que pretende Voltaire es excluir la religión -la verdad divina- del orden social y político, para lo cual la tolerancia y la libertad de conciencia no son más que un caballo de batalla.

\section{LA “ENCYCLOPÉDIE” (1751-1765)}

La Encyclopédie o Dictionnaire raisonné des sciencies, des arts et des métiers ${ }^{89}$ considera la libertad como uno de los valores fundantes de la vida individual, social y social.

Pero, ¿cuál es el concepto de libertad que maneja? En el artículo Libertê ${ }^{\hat{0}}$ se plasma la siguiente definición: "La liberté réside dans le pouvoir qu' un être intelligent a de faire ce qu'il veut, conformément à sa propre détermination" $"$.

Es útil observar que la definición corresponde a la libertad física, pero el artículo la identifica como libertad moral ${ }^{92}$. El "hacer lo que se quiera" en cuanto se tiene el poder de determinarse a sí mismo, es lo que corresponde a la libertad psicológicamente considerada. La única manera de afirmar la equivalencia entre el orden físico-psicológico y el moral es prescindir de toda norma trascendente, convirtiendo a la libertad humana en un referente moral autónomo. En este sentido, la libertad de la Encyclopédie es, desde sus inicios, antitética con la libertad de la filosofía clásica y cristiana, que se encuentra siempre medida por una regla cuyo contenido no es creado ex novo por la voluntad humana, sino que depende de una legalidad superior trasendente, la ley divino-natural.

Una afirmación tan tajante choca, sin embargo, con el ambiente ilustrado de

${ }^{87}$ Ibíd., Conv. 4, pp. 101-128.

${ }^{88}$ Ibíd., Conv. 6, pp. 171-206.

${ }^{89}$ Diderot, Denis - D’Alambert, Jean le Rond, Encyclopédie o Dictionnaire raisonné des sciencies, des arts et des métiers (junio de 1751 a diciembre de 1765), edición digital completa de Flammarion - Le Monde: [http://diderot.alembert.free.fr/]. Aparte de los dos editores Denis Diderot (1713-1784) y Jean Rond d'Alembert (1717-1783), colaboraron en la obra, entre otros, André François le Breton (1708-1789), Étienne Bonnot, abate de Condillac (1714-1780), Paul Henri Thiry, Barón de Holbach (1723-1789), el chevalier Louis de Jaucourt (1704-1779), Anne Robert Jacques Turgot, Barón de Laune (1727-1781), Nicolas Antoine Boulanger (1722-1759), Voltaire, Rousseau y Montesquieu. Sobre la historia de la elaboración de la Enciclopedia: BLOM, Philipp, Encyclopédie. El triunfo de la razón en tiempos irracionales. Historia de la elaboración de la Enciclopedia (1751-1780) (Barcelona, Anagrama, 2007). Sobre los enciclopedistas y las corrientes filosóficas aportadas: GRANADA, M. A. - RiUs, R. - SCHIAVo, P. (editores), Filósofos, filosofía y filosofías en la Encyclopédie de Dideroty d'Alembert (Barcelona, Publicacions i Edicions Univ. Barcelona, 2009).

${ }^{90}$ Diderot, Denis - D’Alambert, Jean le Rond, Encyclopédie o Dictionnaire raisonné des sciencies, des arts et des métiers, cit., s.v. Liberté [http://diderot.alembert.free.fr/L.html]. El artículo es de Louis de Jaucourt (1704-1779) y el orden enciclopédico lo califica como "Morale".

${ }^{91}$ Ibíd.: "La libertad reside en el poder que un ser inteligente tiene de hacer lo que quiera, conforme a su propia determinación".

${ }^{92}$ Como acabamos de referir, la s.v. general Liberté es clasificada como materia "Morale". 
la época, en donde abundan los simpatizantes del deísmo moralizante y de una ley natural afirmada en los sentimientos comunes de la humanidad. Es necesario disimular el concepto radical de libertad desligada con alusiones genéricas a una distinción objetiva entre el bien y el mal, pero formulada de tal manera que en una segunda lectura se vuelva enteramente prescindible: $i$ ) "Les vérités [...] qui sont évidentes [...] entraînent notre consentement, et ne nous laissent aucune liberté [...]. Mais dès que lévidence diminue, la liberté rentre dans ses droits, qui varient et se reglent sur les degrés de clarté ou dobscuritê"; ii) "Les biens et les maux en sont les principaux objets. Elle ne s'étend pas pourtant sur les notions générales du bien et $d u$ mal [...] mais dès qu'il s'agit du détail, notre liberté a un vaste champ, et peut nous déterminer de bien des côtés différens, suivant les circonstances et les motifs" ${ }^{\prime 93}$.

A primera vista, podemos afirmar que: $i$ ) existen verdades evidentes ante las cuales se subordina la libertad humana; y que ii) una de esas verdades es la noción general de bien y de mal. Sin embargo, una lectura más atenta del texto nos descubre un significado más comprometedor. En i) la verdad se presenta como antitética de la libertad. Donde hay verdad no hay libertad, y viceversa. O si se quiere, donde hay verdad la libertad permanece postrada. En ii) el bien y el mal constituyen nociones puramente genéricas, no análogas, por lo que irremediablemente sus determinaciones concretas quedan sujetas a la relatividad de las circunstancias y a la subjetividad de los motivos humanos. El criterio para determinar la moralidad objetiva de una conducta concreta, esto es, la naturaleza de la acción, ni siquiera se enuncia en la cita.

Es desconcertante que, a reglón seguido, el artículo cambie de materia y pase a preocuparse extensamente de la libertad física. Se ensaya una refutación de los sistemas filosóficos que niegan su existencia o merman su naturaleza: el fatalismo, el determinismo psicológico de Leibnitz y el voluntarismo moral. Abundan notorias incongruencias en el tratamiento de estas cuestiones que no podemos tocar aquí. Lo que sí queremos acentuar es que la idea ya enunciada de que la verdad no coincide con la libertad tiene graves consecuencias en el campo moral, y supone presupuestos metafísicos que no son explicitados en el cuerpo del escrito. Hay que presumir que se dejan a merced del lector avisado.

Empero, tales consecuencias se hallan incorporadas, entre otras, en las entradas

${ }^{93}$ Ibíd.: La clasificación es nuestra. "Las verdades [...] que son evidentes [...] arrastran nuestro entendimiento y no nos dejan libertad alguna [...] Pero cuando la evidencia disminuye, la libertad vuelve por sus derechos que se regulan de acuerdo a los grados de claridad o de oscuridad de aquella. Los bienes y los males son los principales objetos de la libertad. Ella no se extiende, por tanto, a las nociones generales de bien y de mal [...], pero en lo que se trata de detalles, nuestra libertad tiene un vasto campo y podemos nosotros determinar el bien de lados diferentes, siguiendo las circunstancias y los motivos”. 
Liberte naturelle $^{94}$, Liberte de penser ${ }^{95}$, Tolérance ${ }^{96}$, Intólerance ${ }^{97}$ e Intolérant ${ }^{98}$, y a su modo, en Libertes de leglise Gallicane ${ }^{99}$.

En la primera entrada referida se afirma la existencia de una libertad natural, previa a cualquier vínculo que la ate, caracterizada por su absoluta autonomía psicológica y moral, especialmente en relación al principio de autoridad: "Le premier état que l homme acquiert par la nature, et qu'on estime le plus précieux de tous les biens qu'il puisse posséder,est létat de liberté; il ne peut ni se changer contre un autre, ni se vendre, ni se perdre; car naturellement tous les hommes naissent libres, c'est-à-dire, qu'ils ne sont pas soumis à la puissance d' un maître, et que personne n'a sur eux un droit de propriété. Et vertu de cet état, tous les hommes tiennent de la nature même, le pouvoir de faire ce que bon leur semble, et de disposer à leur gré de leurs actions et de leurs biens [...]"100.

La influencia rousseauniana de la cita es inequívoca. El idílico estado de naturaleza, liberado de todo yugo de ley tracendente o de autoridad moral o religiosa, define una esencia humana sin vínculos con una verdad. Para aquel estado, la hipótesis de una verdad conocida por vía de autoridad -como la verdad divinallevaría al hombre a una condición de alienación. La libertad de conciencia y de pensamiento no podrían existir.

La Encyclopédie dedica una atención especial a la libertad de pensamiento. El concepto es amplio. Está integrado por la libertad de conciencia que todo hombre tiene para formar por sí mismo las propias creencias morales o religiosas y para decidir y regular su conducta de acuerdo con sus propias reglas. Se incorpora asimismo la libertad de opinión y de enseñanza: cada cual juzga de manera autonoma de todas las cuestiones especulativas o prácticas, y las enseña o difunde públicamente bajo la forma de opiniones, ideas o creencias ${ }^{101}$.

La libertad de pensamiento presupone la existencia de la verdad, pero es una verdad parcial y subjetiva, que no equivale a la manifestación del ser en el entendimiento humano sino a la certeza personal de que una determinada proposición

${ }^{94}$ Ibíd., s.v. Liberté naturelle [http://diderot.alembert.free.fr/L.html]. El artículo es de Louis de Jaucourt (1704-1779). El orden enciclopédico califica la materia como "Droit naturel".

${ }^{95}$ Ibíd., s.v. Liberté de penser en: [http://diderot.alembert.free.fr/L.html]. El artículo se califica como "Morale".

${ }^{96}$ Ibíd., s.v. Tolérance [http://diderot.alembert.free.fr/T.html]. El artículo es de Jean-Edme Romilly (1739-1779). La materia se califica como "Théolog. Morale, Politiq.".

${ }^{97}$ Ibíd., s.v. Intólerance [http://diderot.alembert.free.fr/I.html]. El artículo es de Denis Diderot (1713-1784). Se califica como "Morale".

${ }^{98}$ Ibíd., s.v. Intolérant [http://diderot.alembert.free.fr/I.html]. El artículo es de Louis de Jaucourt. Se califica como "Morale".

${ }^{99}$ Ibíd., s.v. Libertes de l'eglise gallicane [http://diderot.alembert.free.fr/L.html]. El artículo es de Louis de Jaucourt. Se califica como "Jurisp.".

${ }^{100}$ Ibíd., s.v. Liberté naturelle, cit.: "El primer estado que el hombre adquiere por la naturaleza y que se estima como el más precioso de todos los bienes que él pueda poseer, es el estado de libertad; no puede ni sustituirse ni venderse ni perderse, porque naturalmente todos los hombres nacen libres, es decir, no están sometidos al poder de un maestro ni a persona alguna que sobre ellos ejerza un derecho de propiedad [...].”.

${ }^{101}$ Ibíd. 
nos persuade. Así las cosas, la libertad de pensamiento se canaliza a través del principio del libre examen racional y encuentra su modelo en los esprits forts que analizan críticamente todo lo que se les presenta como verdad ${ }^{102}$. Esta actitud es válida especialmente en el campo religioso y moral y debe ser ejercida con particular rigurosidad si dicha verdad proviene del catolicismo. El espíritu tiene que "estar en guardia" contra el "prejuicio" y la "precipitación" (que es fruto de la pereza intelectual), palabras que designan los dos estados de espíritus defectivos que llevan a los hombres a adherir a-críticamente al contenido de la fe cristiana ${ }^{103}$.

En este punto, sin embargo, no ha sido la intención de la Encyclopédie llegar a los extremos de los más ardorosos defensores anglosajones de la libertad de conciencia y de pensamiento, como Anthony Collins (1676-1729) ${ }^{104}$ o Thomas Paine (1737-1809) ${ }^{105}$, que denostan toda verdad religiosa revelada como opuesta a la razón, elaborando teoréticamente una pugna entre ellas. La Encyclopédie es más cuidadosa. Sea porque le preocupe la censura, sea por la creencia genérica de que el mal no está en la religión, sino en la Iglesia y en la sobrenaturalidad del cristianismo (en otras palabras, en la verdad divina), los ataques no suelen ser frontales, salvo cuando se ilustra el ejemplo histórico de la Inquisición. La contraposición entre libertad de conciencia y de pensamiento y verdad divina no se suele presentar de manera abierta, como dos polos en franca beligerancia, sino velada, por medio

${ }^{102}$ Para la Encyclopédie, la libertad de pensar tiene dos sentidos: uno general y otro limitado. El primero significa "esa generosa fuerza de espiritu que liga nuestra persuasión únicamente a la verdad". El segundo, es el resultado del "examen libre y exacto" de lo que se nos propone como verdad, propia de los "espiritus fuertes": "Ces termes, liberté de penser, ont deux sens; l'un général, l'autre borné. Dans le premier ils signifient cette généreuse force d'esprit qui lie notre persuasion uniquement à la vérité. Dans le second, ils expriment le seul effet qu'on peut attendre, selon les esprits forts, d'un examen libre et exact, je veux dire, l' inconviction". Ibíd.

103 "La véritable liberté de penser tient l'esprit en garde contre les préjugés et la précipitation. Guidée par cette sage Minerve, elle ne donne aux dogmes qu'on lui propose, qu'un degré d'adhésion proportionné à leur degré de certitude". Ibíd.: "La verdadera libertad de pensar tiene el espiritu en guardia contra los prejuicios y la precipitación. Guiada por esta sabia Minerva no da a los dogmas que le proponen, más que el grado de adhesión proporcionada a su grado de certidumbre".

${ }^{104}$ Particularmente Collins, Anthony, A Discourse of Freethinking, Occasioned by the Rise and Growth of a Sect called Freethinkers 1713 [La edición del año impresa en Londres se encuentra íntegra en http://books.google.es/books?id=IUsJAAAAQAAJ\&printsec=frontc over \&dq=Anthony+Collins, + Discourse + of + Freethinking \& source $=$ bl\&ots $=$ oUdQr1nds2 \&sig=mShC7LhwgFGBNGuTt8acBhJqRM\&hl=es\&ei=Xi7rS5aoPIHaQb4huDCBA\&sa $=\mathrm{X} \&$ oi $=$ book_result $\& \mathrm{ct}=$ result $\&$ resnum $=3 \& \mathrm{ved}=0 \mathrm{CC} 4 \mathrm{Q} 6 \mathrm{AEwAg} \# \mathrm{v}=$ onepage $\& \mathrm{q} \& \mathrm{f}=\mathrm{fal}$ se]. Una discusión acerca del pensamiento de Collins respecto de Dios, en BENíTEz, Miguel, Anthony Collins revisitado: deismo, panteísmo y ateísmo en los tiempos modernos, en Daimon. Revista de Filosofía, de la Universidad de Murcia, 41 (2007), pp. 25-40.

${ }^{105}$ Especialmente PAIne, Thomas, The Age of Reason, Being an Investigation of True and Fabulous Theology (1794, 1795 y 1807, New York, Philip Sheldon Foner, 1974), donde se enfrenta, con un lenguaje panfletario, contra la religión cristiana, cuyo dogmatismo oprime a la razón y a la libertad [Existe una cuidada versión digital de acuerdo a la edición canónica de Philip S. Foner: parte 1a: [http://www.thomas paine.org/Archives//AOR1.html] y parte $2^{\mathrm{a}}$ : http://www.thomaspaine.org/Archives/AOR2.html]. Sobre la libertad de conciencia en Paine, Pisarello, Gerardo, Vindicación de Thomas Paine, en Revista de Estudios Politicos, 105 (Madrid, 1999), pp. 233-263, particularmente pp. 247-250. 
de un lenguaje sugestivo, ambiguo, disperso, cifrado o aparentemente neutral e inocente, en donde se deja a la tarea del lector el descubrir la lógica profunda del espíritu irreligioso que irriga la nueva doctrina.

Habida consideración del método, el fondo del asunto viene a ser el mismo. La Encyclopédie nos da una imagen de la libertad de conciencia y de pensamiento que es incompatible con la existencia de una verdad divina, revelada, salvífica y magisterial y con una ley moral objetiva y trascendente ${ }^{106}$.

\section{El combate contra el principio de autoridad.}

El principio de autoridad considerado en sí mismo es incompatible con la función crítica de la razón en materias especulativas o morales.

En el artículo Liberté de penser se afecta protestar contra la postura de Collins, que reduce la libertad de pensamiento a la irreligión ${ }^{107}$. Pero se coloca como condición de aquella la toma de distancia respecto de las opiniones recibidas de otros. Lo que quiere decir que la razón no es libre si se somete a ideas sostenidas como verdad por la autoridad religiosa: “C est supposer ce qu' il s' agissoit de prouver,savoir si s'éloigner des opinions généralement reçues, est un caractere distinctif d' une raison asservie à la seule évidence. La paresse et le respect aveugle pour l autorité, ne sont pas les seules entraves de lesprit humain" 108.

¿Podría existir un respeto no "ciego" a la autoridad que, en consecuencia, no fuera una "traba del espíritu humano"? La Encyclopédie no se sitúa en el caso. Pero la explicación es obvia. La religión no pertenece al ámbito de la razón, por lo que cualquier adhesión a una propuesta religiosa que tenga como base de apoyo formal la autoridad de quien la enseña debe ser descartada como una traba. Es lo que profundizamos a continuación.

\section{Las armas de la critica contra la verdad divina.}

Aún en el supuesto de que Dios haya revelado un contenido de fe, éste no tiene por qué estar exento del juicio racional crítico. Lo contrario sería renunciar

${ }^{106}$ Es lo que con agudeza sugiere Clemente XIII en su encíclica Ut primum del 3 de septiembre de 1759, donde devela el sentido anti-cristiano de la Encyclopédie [El documento se encuentra reproducido en su edición facsimil original por el servicio de documentación de Wikisource: http://fr.wikisource.org/wiki/Encyclique_du_pape_Cl\%C3\%A9ment_XIII].

${ }^{107^{\prime \prime}}$ Le traité de la liberté de penser, de Collins, passe parmi les inconvaincus, pour le chef-d'oeuvre de la raison humaine; et les jeunes inconvaincus se cachent derriere ce redoutable volume, comme si c'étoit l'égide de Minerve. On y abuse de ce que présente de bon ce mot, liberté de penser, pour la réduire à l'irreligion; comme si toute recherche libre de la vérité, devoit nécemessairement y aboutir". Diderot, Denis - D’Alambert, Jean le Rond, Encyclopédie, s.v. Liberté de penser, cit.: "El tratado de la libertad de pensamiento de Collins pasa entre los incrédulos, como la obra maestra de la razón humana, y los jóvenes incrédulos se ocultan bajo este temible volumen, como si se tratara de la égida de Minerva. Se abusa así de lo bueno que tiene la palabra libertad de pensamiento para reducirla a la irreligión, como si toda búsqueda libre de la verdad, debiera necesariamente desembocar en tal resultado".

${ }^{108}$ Ibíd.: "El supuesto de lo que se debe probar es saber si el distanciamiento de las opiniones generalmente recibídas es un carácter distintivo de una razón sometida a la sola evidencia. [La respuesta es afirmativa]. La pereza y el respeto ciego por la autoridad no son más que trabas del espíritu humano”. 
a la libertad de pensamiento: "Je suis bien éloigné den conclure qu'il faille pour cela décider au tribunal de la fiere raison, les questions qui ne sont que du ressort de la foi. Dieu n'a point abandonné à nos discussions des mysteres qui, soumis à la spéculation, paroîtroient des absurdités. Dans lordre de la révélation, il a posé des barrieres insurmontables à tous nos efforts; il a marqué un point où lévidence cesse de luire pour nous; et ce point est le terme de la raison; mais là où elle finit, ici commence la foi, qui a droit dexiger de lesprit un parfait assentiment sur des choses qu'il ne comprend pas; mais cette soumission de laveugle raison à la foi, n'ébranle pas pour cela ses fondemens, et ne renverse pas les limites de la connoissance" ${ }^{109}$.

Este párrrafo es notable. Con maestría disimula los ataques a la religión y al cristianismo, figurando respeto hacia esa zona de la fe que los teólogos católicos llaman "misterio" y que en su relación con la razón le atribuyen el carácter de "supra-racional". Es un respeto estratégico envuelto en ambigüedades. A poco que se las analice, se van precisando las siguientes tesis sobre los vínculos entre razón y verdad religiosa:

a) "Où la raison finit, ici commence la foi". La frase puede ser interpretada de dos maneras opuestas: i) Donde termina el dominio de la razón, comienza el de la fe,como la línea que separa en el horizonte la tierra del cielo. Las verdades de fe formalmente consideradas no son demostrables, porque la razón humana no puede alcanzarlas en razón de su imperfección. Es más, ningún entendimiento creado puede comprender las verdades reveladas sobrenaturales. Es la tesis católica de la supra-racionalidad de las verdades dogmáticas; o bien ii) Donde termina el dominio de la razón, comienza el de la fe, porque se cruza la barrera que separa lo inteligible de lo sentimental y subjetivo. Es la tesis ilustrada, firmemente extendida en la Encyclopédie, bajo el velo de una cuidada redacción. Lo que la religión cristiana pretende como verdad no es tal, porque al no poder ser comprendido por la razón -el dogma de la Santísima Trinidad, el de la Encarnación, etc.- es irracional, y debe ser recluido en la antesala del mundo sentimental. De ahí la interrogante que a continuación del texto transcrito el articulista abre a sus lectores: "La religion qui en est l honneur, et qui nous distingue le plus des brutes, n'est-elle pas souvent la chose en quoi les hommes paroissent les moins raisonnables?" 110.

Con el salpicar oportuno de esta ambigüedad, se adelanta que la religión es irracional cuando pretende ser algo más que un vago sentimiento humanitario.

b) La libertad de conciencia y el examen sobre el influjo ilegitimo que las verdades religiosas ejercen sobre nuestra mente, son una y misma cosa: "Elle ramasse sur-tout

${ }^{109}$ Ibíd.: "Estoy lejos de concluir que el tribunal de la razón no pueda fallar al decidir sobre materias que son competencia de la fe. Dios no ha abandonado a nuestras discusiones los misterios que, sometidos a la especulación, no parecen más que absurdos. En el orden de la Revelación, ha puesto barreras insalvables a todos nuestos esfuerzos ; ha marcado un punto donde la evidencia cesa de lucir para nosotros y ese punto es el término de la razón ; más allá donde termina, comienza la fe, que tiene derecho de exigir del espíritu un perfecto asentimiento sobre las cosas que él no comprende ; mas esta sumisión a la fe de la razón ciega, no hace temblar sus fundamentos ni invierte los límites del conocimiento".

${ }^{110}$ Ibíd.: "Pero la religión que constituye el honor del hombre y lo que nos distingue de los brutos, no es también a menudo aquello por lo que los hombres parecen los menos razonables?" 
toutes ses forces contre les préjugés que léducation de notre enfance nous fait prendre sur la religion, parce que ce sont ceux dont nous nous défaisons le plus difficilement; il en reste toujours quelque trace, souvent même après nous en être éloignés"111.

\section{La libertad de conciencia contra la "superstición" católica.}

La superstición es la condición de quienes aceptan una idea religiosa renunciando a ejercer sobre ella la función crítica de la razón ${ }^{112}$. En otros términos, el devoto de la libertad de conciencia no puede ser devoto de la fe cristiana, dado que la conciencia sólo alcanza su madurez cuando rechaza la fe como una verdad dada e iluminadora, a fin de convertirla en su propio producto, previa labor de disección de acuerdo a las necesidades de la propia subjetividad.

\section{Una nueva moral tras los derechos de la conciencia. La cuna del jacobinis-} mo.

Toda la moralidad está en nuestra conciencia, en el motivo que nos mueve a actuar. Si obramos contra nuestros propios sentimientos morales, violentamos nuestra conciencia y nuestra conducta es digna de reproche. Pero si actuamos de acuerdo a nuestra conciencia, no se nos puede imputar un fallo. La maldad está en actuar contra las propias luces, contra la libertad de conciencia autónoma, como dice Romilly: "Ce qui fait l essence du crime, c'est l intention directe d' agir contre ses lumieres, de faire ce qu'on sait être mal, de céder à des passions injustes, et de troubler à dessein les loix de lordre qui nous sont connues; en un mot, toute la moralité de nos actions est dans la conscience, dans le motif qui nous fait agir" 113 .

"Ante los derechos de la conciencia -comenta Eduardo Bello en su análisis sobre la libertad de conciencia en Diderot, Romilly, y otros ilustrados- debe detenerse la intolerancia, tanto la religiosa como la civil. La libertad de conciencia es, pues, la base fundamental no sólo de la defensa de la tolerancia, sino también de la libertad religiosa y de la libertad de pensamiento" 114 . Y lo es porque no existe una verdad en materia religiosa o no es posible al entendimiento humano conocerla con certeza, lo que para efectos vitales viene a ser lo mismo. Romilly en su artículo Tolérance lo dice de esta manera: "Nous le voyons tous les jours, il n'est point de vérité si claire qui n'éprouve des contradictions; il n'est point de système auquel on ne puisse

${ }^{111}$ Ibíd.: "La libertad de conciencia reúne todas sus fuerzas contra los prejuicios religiosos que la educación de nuestra infancia nos ha inculcado, que deshacemos muy difícilmente y de los que siempre queda algún trazo aún cuando estemos distantes de ellos”.

112 "Mais les idées qu'elle s'est faites sur la religion, sont d'une espece respectable pour elle; rarement ose-t-elle les examiner; et l'impression que ces préjugés ont faite sur l'homme encore enfant, ne périt communément qu'avec lui". Ibíd.: "Las ideas que él (el hombre común) se hace de la religión son siempre dignas de respeto, raramente osa examinarlas, y la impresión que esos prejuicios causan en el hombre aún niño, no perecen normalmente más que con él":

${ }^{113}$ Ibíd.: "La esencia del crimen consiste en la intención directa de actuar contra sus propias luces, de hacer aquello que sabe que está mal, de ceder a las pasiones injustas y de perturbar a propósito las leyes del orden que nos son conocidas; en una palabra, toda la moralidad de nuestras acciones está en la conciencia, en el motivo que nos hace actuar”.

${ }^{114}$ BELLO, Eduardo, Tolerancia, verdad y libertad de conciencia en el siglo XVIII, en Isegoría, 30 (Madrid, 2004), p. 132. 
opposer des objections, souvent aussi fortes que les raisons qui le défendent. Ce qui est simple et évident pour P un, paroît faux et incompréhensible à l autre" 115 .

De ahí la necesidad de la tolerancia como escudo de la libertad de conciencia. En términos más precisos, se trata de una tolerancia que viene a identificarse con ésta, pues en la proyección de los ilustrados equivale, en su plena realización, al régimen jurídico de lo que hoy entendemos por libertad de conciencia, de pensamiento y de religión.

Romilly declara que sin la tolerancia no se ven "más que disturbios $y$ disensiones" ${ }^{\prime 16}$. Pero por desgracia la tierra está sembrada de intolerancia. Y de la intolerancia más peligrosa que es la religiosa. A causa de su irracionalidad ha ocasionado los perjuicios más destructores ${ }^{117}$.

El origen de la intolerancia religiosa radica en el postulado de la verdad divina, especialmente cuando viene sostenido por una autoridad magisterial e indiscutible, como la que se atribuye la Iglesia Católica. Esta afirmación exclusivista de la verdad oprime la libertad de conciencia al encadenarla forzosamente a una sola opinión y se agrava cuando la sociedad y el Estado adhieren a ella, cohibiendo la difusión pública de las opiniones disidentes :"C est au milieu des ténebres de la superstition et de lignorance qu' elle ${ }^{118}$ aime à porter ses coups et à répandre ses dogmes impurs; c’est alors qu' au mépris des droits de la conscience et de la raison, elle exerce impunément le despotisme de lintolérance, et gouverne ses propres sujets avec un sceptre de fer; si le sage ose élever sa voix, la crainte létouffe bientôt"119.

La intolerancia en materia de religión, como la de la Iglesia, y más en general, la que proviene del cristianismo, es absurda porque pretende imponer por

115 Diderot, Denis - D’Alambert, Jean le Rond, Encyclopédie, s.v. Tolérance, cit. : "Lo vemos todos los días: no es la verdad tan clara que esté a prueba de contradicciones; no hay sistema al que no se le puedan oponer objeciones, a menudo tan fuertes como las razones que la defienden. Lo que es simple y evidente para uno, es falso e incomprensible para otros".

116 "[...] sans lesquelles (la tolerancia) on ne verroit sur la terre que troubles et dissentions". Ibíd.

117 "On peut compter sans doute plusieurs sources de nos discordes [...] mais comme c'est surtout en matiere de sentiment et de religion, que les préjugés destructeurs triomphent avec plus d'empire, et des droits plus spécieux, c'est aussi à les combattre que cet article est destiné". Ibíd.: "Se pueden contar muchas causas de nuestras disensiones [...] pero como es sobre todo en materia de sentimientos y de religión que los perjuicios destructores triunfan con más fuerza, es a combatirlos a ellos que este artículo está destinado".

${ }^{118}$ Se refiere a la Iglesia Católica que no nombra en este pasaje, pero que designa con caracteres inequívocos, personificando en Ella la intolerancia. Con los más negros tintes pinta Romilly la intolerancia religiosa práctica -fautora de todos los crímenes habidos y por haber-: "Les crimes les plus atroces, les parjures, les calomnies, les trahisons, les parricides; tout est justifié par la cause, tout est sanctifié par le motif, l'intérêt de l'Eglise, la nécessité d'étendre son regne, et de proscrire à tout prix ceux qui lui résistent, autorise et consacre tout [...]. La religion donnée aux hommes pour les unir et les rendre meilleurs, devient le prétexte même de leurs égaremens les plus affreux; tous les attentats commis sous ce voile sont désormais légitimes". Ibíd.:

${ }^{119}$ Ibíd.: "Es en medio de las tinieblas de la superstición y de la ignorancia que ella [la Iglesia] ama dispensar sus golpes y derramar sus dogmas impuros; es entonces, en la hora del desprecio de los derechos de la conciencia y de la razón, cuando ella ejerce impunemente el despotismo y la intolerancia, y gobierna sus súbditos con un bastón de hierro; si la honestidad osa elevar su s.v., el temor la acalla”. 
la violencia una opinión en desmedro de otras. Lo que atenta, en primer lugar, contra la naturaleza de la razón y de la conciencia que suponen la adhesión libre a las ideas y creencias; y en segundo lugar, contra la esencia de la verdad que se comunica por el discurso y se recibe con el asentimiento y no por la fuerza del hierro o de la hoguera ${ }^{120}$.

Nada puede justificar tal opresión de la conciencia:"Si je brave les tourmens et la mort pour conserver ce qui m' est plus précieux que la vie, les droits de ma conscience et de ma liberté, que voyez-vous dans ma persévérance qui mérite votre indignation?" 121.

En la cuestión de la tolerancia/intolerancia, la Encyclopédie, como más ampliamente los ilustrados, no distinguen entre las diversas maneras en que la conciencia humana pueda ser afectada. Les parece que, a todo evento, en materia religiosa y moral, la conciencia del hombre es siempre inmune a toda exigencia o legalidad externa porque a diferencia del ámbito político mantiene siempre su autonomía derivada de la libertad natural. Por lo que la responsabilidad de la intolerancia práctica pertenece, en último término, a una actitud teórica: la afirmación exclusiva de una verdad divina -lo que llamamos intolerancia especulativa- que en la especie es la verdad cristiana, principio de todos los males: "On renouvelle pour le Dieu des Chrétiens le culte abominable de Saturne et de Moloch, l audace et le fanatisme triomphent, et la terre voit avec horreur des monstres déifiés" 122.

Romilly, que es un pastor protestante ginebrino de formación ilustrada, se da cuenta de los presupuestos escépticos de esta sentencia, que arrumba la afirmación de que una sociedad política cristiana es buena y deseable. Por ello, al final de su artículo sobre la tolerancia, intenta eximirse de una responsabilidad excesiva declarando que él no sustenta la tolerancia especulativa sino la práctica, lo que equivale a decir que bien se puede defender la última sin caer en el escepticismo epistemológico, moral y religioso.

120 "De tous les moyens qu'on emploie pour arriver à quelque but, la violence est assurément le plus inutile et le moins propre à remplir celui qu'on se propose. Quel est donc le but des persécuteurs? De convertir ceux qu' ils tourmentent; de changer leurs idées et leurs sentimens pour leur en inspirer de contraires; en un mot, de leur donner une autre conscience, un autre entendement. Mais quel rapport y a-t-il entre des tortures et des opinions? Ce qui me paroît clair, évident, me paroîtra-t-il faux dans les souffrances? Une proposition que je vois comme absurde et contradictoire, sera-t-elle claire pour moi sur un échafaud? Est-ce, encore une fois, avec le fer et le feu que la vérité perce et se communique?". Ibíd.: "De todos los medios que se emplean para arribar a alguna meta, la violencia es seguramente la más inútil y la menos propia para alcanzar aquello que se propone. ¿Cuál es la meta de los perseguidores? Convertir a los que se fueron, cambiar sus ideas y sentimientos para inspirarles los contrarios; en una palabra, darles otra conciencia, otro entendimiento [...]. ¿Qué relación hay entre las torturas y las opiniones? Lo que me parece claro, evidente, me parecerá falso en los sufrimientos? Una proposición que yo veo como absurda y contradictoria, será clara para mi bajo el cadalso? Una vez más, ¿es con el hierro y con la hoguera que la verdad taladrada se comunica?".

${ }^{121}$ Ibíd.: "Si yo enfrento los tormentos y la muerte para conservar aquello que me es más precioso que la vida, los derechos de mi conciencia y de mi libertad, que veis en mi perseverancia que amerite vuestra indignación?”.

${ }^{122}$ Ibíd.: "Se renueva para el Dios de los cristianos el culto abominable de Saturno y de Moloch, la audacia y el fanatismo triunfante, y la tierra ve con horror a sus monstruos deificados". 
Sigue: "Nous prêchons la tolérance pratique, et non point la spéculative; et lon sent assez la différence qu' il y a entre tolérer une religion et l approuver. Nous renvoyons les lecteurs curieux d approfondir ce sujet au commentaire philosophique de Bayle, dans lequel selon nous, ce beau génie s'est surpassê" 123 . La primera frase, como se aprecia, es una declaración puramente retórica, desmentida por el análisis de fondo que el propio autor hace a lo largo de su artículo, que abona la interpretación escéptica. Y como si eso no bastara, y a fin de despejar toda duda, el autor nos reenvía, a continuación, al "Comentario filosófico" de Bayle, que, como sabemos, no sólo defiende el escepticismo, sino que positivamente es interpretado escépticamente por los enciclopedistas.

Lenguaje engañoso el de Romilly que requiere ser completado con la definición de intolerancia que formula Diderot. Su artículo Intólerance es un escrito más preciso, más directo, en el que distingue entre una intolerancia eclesiástica y una intolerancia civil. La primera es la que profesa la Iglesia Católica: "L'intolérance écclésiastique consiste à regarder comme fausse toute autre religion que celle que lon professe, et à le démontrer sur les toîts, sans être arrêté par aucune terreur, par aucun respect humain, au hasard même de perdre la vie" ${ }^{124}$.

Observemos cómo Diderot ya no se molesta en discernir entre intolerancia especulativa y práctica. Están fundidas a fin de estigmatizarlas en conjunto porque a una se la concibe como el pivote de la otra. Lo mismo sucede con la noción de intolerancia civil. Si la sociedad y el Estado profesan una fe determinada significa en la práctica que hay opresión de conciencia de quienes piensan distinto ${ }^{125}$.

El Estado confesional cristiano es ilegítimo. Sólo tiene derecho a existir el Estado laico. Es por eso que, volviendo a Romilly, la Encyclopédie establece la siguiente "regla general": "Les erreurs spéculatives sont indifférentes à létat; la diversité des opinions régnera toujours parmi des êtres aussi imparfaits que l homme; la vérité produit les hérésies comme le soleil des impuretés et des taches" ${ }^{\prime 26}$.

La última frase no podría exponer la tesis con una metáfora más adecuada: la verdad, esto es, un cuerpo doctrinario que es propuesto como verdad divina por la Iglesia y que para la sociedad cristiana es ortodoxia, produce heterodoxia, como el sol impurezas. En el medio hispano, y haciéndose eco de la doctrina ilustrada,

${ }^{123}$ Ibíd.: "Nosotros predicamos la tolerancia práctica y no la especulativa; se siente la diferencia que hay entre tolerar una religión y aprobarla. Nosotros reenviamos a los lectores curiosos a profundizar esta materia en el comentario filosófico de Bayle, en donde según nosotros, ese bello genio se supera a sí mismo".

124 "La intolerancia eclesiástica consiste en mirar como falsa toda otra religión que no sea la que se profesa y en demostrarlo por todos los medios, sin retroceder ante ningún terror, ante ningún respeto humano, incluso ante el evento de perder la vida”. Ibíd., s.v. Intólerance, cit.

${ }^{125}$ "L'intolérance civile consiste à rompre tout commerce et à poursuivre, par toutes sortes de moyens violens, ceux qui ont une façon de penser sur Dieu et sur son culte, autre que la nôtre”. Ibíd.: "La intolerancia civil consiste en romper todo vínculo y en perseguir, por toda suerte de medios violentos, a aquellos que tienen una manera de pensar sobre Dios y sobre su culto, distinta que la nuestra".

126 "Los errores especulativos son indiferentes al Estado; la diversidad de opiniones regenera siempre a seres tan imperfectos como los hombres; la verdad produce las herejías como el sol las impurezas y las manchas". Ibíd., Tolérance, cit. 
Eduardo Bello ha desenvuelto el sentido de esta frase: "La verdad produce herejes como el sol impurezas". ¿ Por qué la verdad produce herejes? Porque se define previamente un cuerpo de doctrina, a la que se califica de verdadera, sobre una triple base: la sagrada Escritura, una determinada tradición y una sola interpretación: la de la Iglesia católica. Se afirma luego el principio de identidad o de uniformidad, mediante el calificativo "ortodoxa"; de modo que, frente a ésta, todo otra doctrina es "heterodoxa”. Más aún: la doctrina ortodoxa, puesto que es la única verdadera, es universalizable. Si tal es la única doctrina verdadera, todos tienen que adherirse a ella como única vía de salvación: "sólo dentro de la Iglesia hay salvación", reza el lema que ha guiado durante siglos tanto al teólogo como al párroco, tanto al predicador como al misionero, pero también al inquisidor, al perseguidor y al torturador. En consecuencia, todo el que se desvíe de la doctrina ortodoxa es un "hereje”. La herejía no es sino la tesis en desacuerdo con la doctrina ortodoxa, la única verdadera, definida por la Iglesia católica, esto es, universal"127.

El texto nos permite percibir cómo la tesis ilustrada -así como su carácter confuso- llega hasta nuestros días. Como Romilly, Bello sostiene que la afirmación de la verdad divina supone una actitud mental ilegítima de intolerancia especulativa, la que, por consecuencia necesaria, comporta la intolerancia práctica y su cúmulo de odiosidades injustas y de crímenes contra nuestros semejantes.

El salto lógico entre intolerancia especulativa e intolerancia práctica es patente. Ni una conduce a la otra necesariamente (podemos y solemos distinguir entre el error y el que yerra), ni la intolerancia práctica es siempre un crimen (una sociedad puede y debe defender la fe como bien público, cuando cree en ella, con medios jurídicos no reñidos con la ley natural), ni quienes atacan la fe son siempre justos (se puede querer arrumbar la fe de una sociedad con todos los medios posibles, los arteros y los violentos).

Estas distinciones, sin embargo, no valen para la Encyclopédie. Se puede decir que nada vale, mientras no se acepte que la religión no pasa de ser un sentimiento sin homologación racional, que debe quedar excluida de la vida pública -"les erreurs spéculatives sont indifférentes à létat" - y que la libertad de conciencia debe entenderse como un derecho para desvincularse de la verdad divina y de toda legalidad trascendente. Que la verdad produce herejes como el sol impurezas en una ulterior lectura quiere decir que para los ilustrados tanto vale una como la otra, porque ambas son meras opiniones humanas. Y como es frecuente que una opinión sea ocasión de otra opinión contraria, lo mejor es que ambas se pierdan en los espacios de la libertad individual.

$\mathrm{Al}$ respecto, Diderot, en el artículo citado, precisa que la esencia de la intolerancia consiste precisamente en oponer la verdad al error, de tal modo que cual pasión feroz terminamos odiando a quien ubicamos en el error ${ }^{128}$. En igual sentido, en la entrada correspondiente a la voz Intolérant, Jaucourt afirma que el intolerante es

${ }^{127}$ Bello, Eduardo, cit. (n. 114), p. 130

128 "Le mot intolérance s'entend communément de cette passion féroce qui porte à haïr et à persécuter ceux qui sont dans l'erreur". Diderot, Denis - D’AlamberT, Jean le Rond, Encyclopédie, s.v. Intólerance, cit.: "La palabra intolerancia se entiende comúnmente de esa pasión feroz que odia y persigue a aquellos que están en el error". 
el perseguidor, que trata como a una bestia cruel a su semejante, por el solo hecho de tener una opinión distinta de la suya. E inmediatamente identifica la causa: "L' intolérant ou le persécuteur, est celui qui oublie qu' un homme est son semblable, et qui le traite comme une bête cruelle, parce qu' il a une opinion différente de la sienne. La religion sert de prétexte à cette injuste tyrannie, dont leffet est de ne pouvoir souffrir une façon de penser différente de la sienne, tandis que sa véritable source vient de laveuglement, de la présomption, et de la méchanceté du coeur humain. Elle est si grande cette méchanceté, que tout homme de lettres, qui cherche ici bas le repos, doit sans-cesse prier Dieu de lui faire trouver grace auprès des intolérans" ${ }^{129}$.

Si la intolerancia especulativa es "la fuente de todos los males", la tolerancia traerá el pluralismo religioso, una era mítica de paz y felicidad de múltiples notas que compondrán una gran sinfonía armoniosa ${ }^{130}$. No obstante, por detrás de esta interesada promesa de futuro, ya se vislumbra la futilidad de las religiones, en un mundo que convive con ellas a cuenta de no tomárselas en serio en la vida pública.

Es que los malvados son los intolerantes y los buenos son los tolerantes. Los primeros se identifican primordialmente con los intolerantes especulativos, esto es, con quienes adhieren a una verdad divina, especialmente la católica, con su código moral correspondiente. No hay que esperar nada de ellos pues llevan la maldad en su corazón. Queda trazado así el perfil psico-doctrinario del enemigo de la tolerancia ilustrada. Una vez más, la tolerancia se tonifica de fuerza anti-cristiana y se vuelve intolerante. Con este enemigo, no puede haber tolerancia, como afirma Voltaire por la misma época, en un pasaje que hemos citado más arriba.

El discurso jacobino se empapará en esta fuente para acometer sus crímenes invocando el discurso de la libertad. Porque el problema para los ilustrados y sus herederos revolucionarios es esencialmente político: hay que derrumbar el orden en el que vive y cree la sociedad antigua para suplantarlo por un nuevo estado de cosas en el que el hombre colectivo se vuelva libre a costa de liberarse de todo límite trascendente.

129 "La religión sirve de pretexto a esta injusta tiranía, porque no puede sufrir una manera de pensar diferente de la suya, mientras la verdadera fuente viene de la obcecación, de la presunción y de la maldad del corazón humano. Es tan grande esta maldad, que todo hombre de letras, que busque aquí el reposo, debe sin cesar rogar a Dios, para hallar gracia de parte de los intolerantes". Ibíd., s.v. Intolérant, ed. cit.

130 "Mais que de maux, que de divisions n'entraîne pas dans un état la multiplicité de la religion? Mais que de maux, que de divisions n'entraîne pas dans un état la multiplicité de la religion? L'objection se tourne en preuve contre vous, puisque l'intolérance est elle-même la source de ces malheurs; car si les partis différens s'accordoient un mutuel support, et ne cherchoient à se combattre que par l'exemple, la régularité des moeurs, l'amour des loix et de la patrie [...] l' harmonie et la paix régneroient bien-tôt dans l'état, malgré la variété d'opinions, comme les dissonnances dans la musique ne nuisent point à l'accord total”. Ibíd.: “Qué hay de malo para un Estado en la división que entraña la diversidad de religiones? La objeción se vuelve contra vos, porque la intolerancia es ella misma la fuente de los males; porque si los partidos diferentes se acordaran un mutuo respeto, y no buscaran combatirse más que por el ejemplo; la regularidad de las costumbres, el amor a las leyes y a la patria [...] la armonía y la paz reinarían en el estado, entre la variedad de opiniones, como las disonancias en la música no dañan el acuerdo total". 


\section{El escepticismo epistemológico como dogma ilustrado. Hacia la libertad de la} religión.

Diderot, en el artículo referido, describe en frases de gran riqueza sintética lo que le parecen ser las aporías de la verdad religiosa: "Il y a des circonstances où lon est aussi fortement persuadé de lerreur que de la vérité. Cela ne peut être contesté que par celui qui n'a jamais été sincerement dans lerreur"131. Añade: "Si votre vérité me proscrit, mon erreur que je prends pour la vérité,vous proscrira"132. Todavía:" Cessez dêtre violens, ou cessez de reprocher la violence aux Payens et aux Musulmans"133.

Estas aporías tienen como fondo común un presupuesto especulativo del más alto calado: la verdad religiosa no existe. Sostener que el cristianismo es verdadero no tiene sentido. Cada cual debe tener sus propias convicciones sin sentirse vinculado a un Dios que dice haber traído a los hombres un mensaje de salvación.

La libertad de conciencia y de religión es concebida como una libertad de la religión y no una libertad de religión. Se trata de una libertad para liberarse de las ataduras de la verdad y no una libertad del hombre para buscar al Dios verdadero. La verdad impide que el hombre sea libre. Por eso Diderot afirma: "La religion se persuade et ne se commande pas. L' homme doit être libre dans le choix de son culte; le persécuteur fait haïr son Dieu"134.

En Diderot, el vocablo "verdadero" adopta el cariz negativo de lo que se manda, y que, por tanto, no necesita de la persuasión. La persuasión religiosa, en cambio, tiene que ver con el sentimiento, $y$, en consecuencia, queda al libre arbitrio de la conciencia, sin que sea posible exigir deber alguno. Por eso, la libertad religiosa es una libertad para elegir el propio culto, según el propio gusto. En este plano, corresponde a los ilustrados dirigir a los ciegos que no quieren ver tan simple realidad ${ }^{135}$.

${ }^{131}$ Ibíd., s.v. Intólerance, cit. "Hay circunstancias en las que se está tan fuertemente persuadido del error como de la verdad. Esto no puede ser contestado más que por quien no ha estado jamás sinceramente en el error". Con un giro análogo, proclama Romilly: "On n'adopte point l'erreur comme erreur; on peut quelquefois y persévérer à dessein par des motifs intéressés, et c'est alors qu'on est coupable. Mais je ne conçois pas ce qu'on peut reprocher à celui qui se trompe de bonne foi, qui prend le faux pour le vrai sans quion puisse l'accuser de malice ou de négligence". Ibíd., s.v. Tolérance, cit. "Uno no adopta el error como error; si algunas veces persevera en ellos por motivos de interés nos hacemos culpables, pero no conozco a nadie que se haya engañado de buena fe, que haya tomado lo falso por lo verdadero sin que se le pueda acusar de malicia o negligencia".

${ }^{132}$ Ibíd.: "Si vuestra verdad me proscribe, mi error que yo tomo por verdad, os proscribirá".

${ }^{133}$ Ibíd.: "Cesad de sed violentos, o cesad de reprochar violencia a los paganos y a los musulmanes".

134 "La religión se persuade y no se manda. El hombre debe ser libre en la elección de su culto; la persecución hace odioso a Dios". Ibíd.:

${ }^{135}$ Una de las ideas que rondan la Carta sobre los ciegos para uso de los que ven de Diderot, en un estilo literario caracterizado por amplias figuras y metáforas, es que la labor de los philosophes consiste en "hacer caer el velo de los ojos" con "todas sus consecuencias". Diderot, Carta sobre los ciegos para uso de los que ven (Valencia, Fundación Once y editorial Pre-Textos, 2002), p. 9. Los ciegos no ven porque no pueden usar la vista. Tocan sin conocer. En su aplicación religiosa esto significa que no quieren usar su razón. Más adelante precisa: "Tampoco se corresponde mejor nuestra metafisica con la suya [la de los ciegos]. ¡Cuántas cosas que son 
Contra Diderot, hemos de observar que el culto no se elige pura y simplemente, al menos en el sentido material de optar entre distintos objetos de los que podemos prescindir a nuestro antojo. Cuando se acepta el estatuto de la verdad religiosa, el culto arrastra, porque arrastra la verdad del Dios solícito. En otras palabras, el culto atrae a la voluntad en la medida en que se trata de una realidad sustancialmente vertical, referida a un Ser superior, que exige homenaje a través de la rendición de aquella. Rendición que es libre, pero no arbitraria.

Pero el Dios cristiano está lejos de los esquemas conceptuales de la Ilustración. Los enciclopedistas lo saben y por eso su defensa de la tolerancia, cuadro jurídico de la libertad religiosa, está teñida de escepticismo.

El escepticismo, en el sentido de incapacidad de la razón para conocer las verdades de orden metafísico, moral o religioso, es señalado expresamente por Romilly, como necesario para fundar la libertad religiosa. Podemos hablar, si se quiere, de un escepticismo relativo, en cuanto se acepta que el ser humano puede alcanzar unas cuantas verdades comunes; sin embargo, más allá de ellas, no se puede tener certeza objetiva de nada. Y aún aquellas verdades comunes son tan genéricas, que poco sirven para hilvanar los acuerdos humanos en materias especulativas o morales. Es este escepticismo relativo el que legitima éticamente la tolerancia como virtud transversal primaria en el campo de la filosofía, la religión y la moral.

En su artículo sobre la Tolérance, Romilly defiende un escepticismo epistemológico. Es la propia estructura del entendimiento humano la que le conduce a un conocimiento extremadamente inseguro de la verdad: "La raison humaine n'ayant pas une mesure précise et déterminée, ce qui est évident pour l un est souvent obscur pour lautre; lévidence n'étant, comme on sait, qu'une qualité relative, qui peut venir ou du jour sous lequel nous voyons les objets, ou du rapport qu'il y a entre eux et nos organes,ou de telle autre cause; en sorte que tel degré de lumiere suffisant pour convaincre l un, est insuffisant pour un autre dont lesprit est moins vif, ou différemment affecté, doù il suit que nul n'a droit de donner sa raison pour regle, ni de prétendre asservir personne à ses opinions. [...]. Il est donc clair que nous avons tous notre maniere de voir et de sentir, qui ne dépend que bien peu de nous. L'éducation, les préjugés, les objets qui nous environnent, et mille causes secrettes, influent sur nos jugemens et les modifient à linfini" ${ }^{136}$.

principios para ellos se nos antojan a nosotros absurdas!, y recíprocamente. Podría entrar aquí en unos detalles que os divertirían, sin duda, pero que algunas personas a quienes todo les parece criminal no dudarían en acusar de irreligión; como si dependiera de mí hacer que los ciegos percibieran las cosas de manera distinta a como las perciben”. Ibíd., p. 20.

${ }^{136}$ Diderot, Denis - D’Alambert, Jean le Rond, Encyclopédie, s.v. Tolérance, cit. "La razón humana no tiene una medida precisa y determinada, lo que es evidente para uno frecuentemente es oscuro para otro; la evidencia, como se sabe, no es más que una cualidad relativa que proviene, o de la claridad bajo la cual vemos los objetos, o de las relaciones que ellos tienen con nuestros órganos, o de otra causa. De suerte que un tal grado de luz suficiente para convencer a uno, es insuficiente para convencer a otro, sea porque el espíritu es menos vivo, o ha sido diferentemente afectado. De donde se deduce que no existe ningún derecho para imponer a su razón una regla ni pretender someter a nadie a sus opiniones [...]. Es pues claro que tenemos nuestra manera de ver y de sentir, que depende bien poco de nosotros. La 
A mayor abundamiento, más que evidencias tenemos certezas, y la mayor parte de las veces son subjetivas y provisorias ${ }^{137}$, lo que es particularmente sensible en materia moral y religiosa: Le monde moral est encore plus varié que le physique; et les esprits se ressemblent moins que les corps. Nous avons, il est vrai, des principes communs sur lesquels on s'accorde assez; mais ces premiers principes sont en très-petit nombre, les conséquences qui en découlent deviennent toujours moins claires à mesure qu' elles s'en éloignent; comme ces eaux qui se troublent en s'éloignant de leur source ${ }^{138}$.

Los resultados lógicos del postulado escéptico - pues, se trata, en definitiva de una proposición que no se prueba, sino que se asume dogmáticamente- son ineludibles:

i) A nivel individual, la afirmación del principio universal de la libertad de conciencia, en el sentido moderno de libertad desligada, de liberación de la razón crítica a-religiosa.

ii) En el plano veritativo, el postulado de la ilegitimidad moral del deber de buscar a Dios y adherirse a la verdad divina revelada.

iii) En el ámbito político, la ineludible imposición del régimen de tolerancia absoluta en materia religiosa y moral, que se identifica con lo que hoy denominamos libertad de conciencia, de pensamiento y de religión en el ordenamiento jurídico del Estado laico.

\section{La mascarada del laicismo en ebullición.}

Si la verdad religiosa no puede ser conocida como tal, es inadmisible que ella tenga pretensiones de verdad divina en el orden político y social, por más que la población crea en ella. ¿Cómo se promueve/impone institucionalmente la libertad de conciencia y de religión a un pueblo que adhiere a la verdad cristiana?

El proceso de promoción e imposición corre por hendiduras aparentemente razonables. ¡Feliz el que sepa conocer la verdad! prorrumpe la Encyclopédie, pero mientras ello no sea posible, o no sea reconocido por todos, ¿qué hay de más natural que aproximarnos unos a otros a través de la libertad religiosa?

La Encyclopédie no habla de libertad religiosa sino de libertad de conciencia, de pensamiento, de opinión o de cultos, según el contexto. Pero para designar el régimen político que consagra la libertad de cultos y de opinión emplea más frecuentemente el término de "tolerancia", según el uso de la época. Se trata de una tolerancia que, por sus supuestos doctrinarios peculiares, sólo sigue parcialmente el significado común de soportar o no impedir un mal.

educación, los prejuicios, los objetos que nos rodean y miles de causas secretas, influyen sobre nuestros juicios y los modifican hasta el infinito".

137 "Combien de fois j'ai cru voir le vrai, où dans la suite j'ai reconnu le faux? combien j'en ai condamné, dont j'ai depuis adopté les idées?". Ibíd.: "Cuantas veces he creido ver la verdad, y cuando la he seguido he reconocido el error? Cuantas veces he condenado aquellas ideas que después he adoptado?":

138 "El mundo moral es aún más variado que el físico, y los espíritus se parecen menos que los cuerpos. Tenemos, es verdad, principios comunes en torno a los que llegan a algunos acuerdos; pero esos primeros principios son muy pocos, y las consecuencias que se derivan son siempre menos claras en la medida en que se alejan de ellos, como las aguas que se enturbian al distanciarse de la fuente". Ibíd. 
Es cierto que la Encyclopédie recoge este uso, pero con una modificación importante que nos indica la pista para comprender la mutación de significado. El artículo Tolérer dice: "Tolérer, souffrir, permettre (Synonymes). Tolérer ne se dit que pour des choses mauvaises, ou qu'on croit telles; permettre se dit pour le bien et le mal"139. La clave aquí es la frase "lo que uno cree como tal". En efecto, aplicada esta acepción de tolerancia a la religión, resulta que no hay nada que tolerar. O si se prefiere, como dice Romilly, todos se soportan, todos se toleran, porque nadie sabe a ciencia cierta si acaso lo que juzga como un error religioso es realmente tal o si lo que conoce como verdad es realmente la verdad ${ }^{140}$. De ahí que el régimen de tolerancia se manifieste como un régimen de libertad de cultos y de opinión ${ }^{141}$.

El régimen de libertad religiosa lleva al repudio de la unidad política católica o del Estado confesional protestante. Entendamos, una vez más, que no se trata de un rechazo prudencial, en atención al pluralismo de hecho existente en una sociedad determinada, sino de una cuestión de principios: la unidad política religiosa es una "perfección" indeseable, pues es incompatible con la naturaleza humana. La diversidad de religiones corresponde a la multiplicidad de meras opiniones subjetivas que nacen de los sentimientos innatos en los hombres. La profesión de la fe cristiana en la vida pública sólo se logra a costa de convertir al hombre en un autómata. Una vez más es Romilly quien esclarece el principio:

\footnotetext{
${ }^{139}$ Ibíd., s.v. Tolérer. "Tolerar, sufrir, permitir. Tolerar no se dice más que de las cosas malas, o que uno cree tales; permitir se dice para el bien y el mal".

${ }^{140}$ Un pasaje entre otros del artículo Tolérance: "mille chemins conduisent à l'erreur, un seul mene à la vérité: heureux qui sait le reconnoître! Chacun s'en flatte pour son parti, sans pouvoir le persuader aux autres; mais si dans ce conflit d'opinions, il est impossible de terminer nos différends, et de nous accorder sur tant de points délicats, sachons du-moins nous rapprocher et nous unir par les principes universels de la tolérance et de l'humanité, puisque nos sentimens nous partagent, et que nous ne pouvons être unanimes. Qu'y a-t-il de plus naturel que de nous supporter mutuellement?". Ibíd., s.v. Tolérance, cit.: "Mil caminos conducen al error, uno solo lleva a la verdad: feliz el que sepa reconocerla! Cada uno se halaga en su partido, sin poder persuadir a los otros; pero si en el conflicto de opiniones, es imposible terminar con nuestras diferencias, y de nuestro acuerdo sobre tantos puntos delicados, sabemos al menos aproximarnos y unirnos por los principios universales de la tolerancia y de la humanidad, porque compartimos nuestros sentimientos en aquello que no podemos ser unánimes. ¿Qué hay de más natural que soportarnos mutuamente?".

${ }^{141}$ Romilly afirma al respecto: "mais ne confondez point avec ces coupables ceux qui ne vous demandent que la liberté de penser, de professer la croyance qu' ils jugent la meilleure, et qui vivent d'ailleurs en fideles sujets de l'état". Ibíd.: "No se debe confundir con los culpables aquellos que no demandan sino la libertad de pensar, de profesar la creencia que se juzge mejor y que vivan además como fieles súbditos del Estado". "Je ne crois pas quion m'oppose l'objection si souvent foudroyée, que la véritable Eglise étant seule en droit d'employer la violence et la contrainte, les hérétiques ne pourroient sans crime agir pour l'erreur, comme elle agit pour la vérité; un sophisme si puérile porte avec lui sa réfutation; qui ne voit en effet qu'il est absurde de supposer la question même, et de prétendre que ceux que nous appellons hérétiques se reconnoissent pour tels, se laissent tranquillement égorger et s'abstiennent de représailles?". Ibíd.: "No creo que se me pueda oponer la objeción frecuentemente refutada, de que sólo la verdadera Iglesia tiene el derecho de emplear la violencia y la cohibición, y los herejes no podrían sin crimen actuar por error, como ella actúa por la verdad; un sofisma tan pueril trae en sí mismo su refutación. ¿Quién no ve, en efecto, que es absurdo suponer la cuestión misma, y pretender que aquellos que llamamos heréticos se reconocen por tales, y se dejan tranquilamente degollar y se abstienen de represalias?"
} 
"Pourquoi prétendre à une perfection incompatible avec notre nature? la diversité des sentimens subsistera toujours parmi les hommes; l histoire de lesprit humain en est une preuve continuelle; et le projet le plus chimérique seroit celui de ramener les hommes à Puniformité d'opinions. Cependant, dites-vous, Pintérêt politique exige qu'on établisse cette uniformité; qu'on proscrive avec soin tout sentiment contraire aux sentimens reçus dans létat, c'est-à-dire, qu'il faut borner l homme à n'être plus qu'un automate, à linstruire des opinions établies dans le lieu de sa naissance, sans jamais oser les examiner, ni les approfondir, à respecter servilement les préjugés les plus barbares, tels que ceux que nous combattons ${ }^{142}$.

Se encuentra en la filigrana de este pasaje los trazos del laicismo francés, que tal como quedó configurado en la Revolución de 1789, es un laicismo de combate porque entiende la libertad religiosa como libertad contra la verdad divina, y lo laico como expulsión del Dios cristiano de la vida pública y social ${ }^{143}$. Estos trazos se vuelven explícitos en diferentes lugares de la Encyclopédie:

i) Proclamación de la independencia del Estado francés respecto de la potestad espiritual del Papa, sea directa o indirecta, subrayando las tesis galicanas ${ }^{144}$.

ii) Negación del principio de defensa temporal de la fe como un bien social y político. La doctrina del brazo secular es repudiada por ser opuesta a la naturaleza de la religión -que sólo podría ser sustentada por la exhortación-y por ser contraria a los deseos de Cristo, que quiso la paz y no la guerra ${ }^{145}$.

${ }^{142}$ Ibíd.: “PPor qué pretender una perfección incompatible con nuestra naturaleza? La diversidad de sentimientos subsistirá siempre entre los hombres; la historia del espíritu humano es una prueba contínua, y el proyecto más quimérico sería reducir a los hombres a una uniformidad de opiniones. Entretanto, se me dirá, el interés político exige que se establezca esta uniformidad; que se proscriba con cuidado todo sentimiento contrario a los sentimientos recibídos en el Estado; es decir, es necesario limitar al hombre para que no sea más que un autómata, instruirlo con opiniones estables desde su nacimiento, sin que jamás ose examinarlas, ni profundizarlas; que respete servilmente los prejuicios más bárbaros, tales como aquellos que nosotros combatimos".

${ }^{143}$ La mirada despreciativa hacia la religión se hace patente en Voltaire, que presenta en negativo la fotografía que en positivo hace la Encyclopédie sobre la necesidad del escepticismo religioso. Véase, por ejemplo, el siguiente pasaje de su Discurso sobre la libertad citado en el artículo Liberté de penser de la Encyclopédie, cit.: "Il le croyoit donc libre? Oui, sans doute; et lui-même Dément à chaque pas son funeste système/ Il mentoit à son coeur, en voulant expliquer Le dogme absurde à croire, absurde à pratiquer/ Il reconnồt en lui le sentiment qu' il brave; Il agit, comme libre, et parle comme esclave".

144 "Nos libertés [...] se rapportent néanmoins à deux maximes fondamentales. La premiere, que le pape et les autres supérieurs ecclésiastiques n'ont aucun pouvoir direct ni indirect sur le temporel de nos rois, ni sur la jurisdiction séculiere. La seconde, que la puissance du pape, par rapport au spirituel, n'est point absolue sur la France, mais qu'elle est bornée par les canons et par les coutumes qui sont observés dans le royaume; desorte que ce que le pape pourroit ordonner au préjudice de ces regles, est nul". Ibíd., s.v. "Libertes de l'eglise gallicane", cit.: "Nuestras libertades nos traen dos máximas fundamentales: la primera, que el papa y los otros superiores eclesiásticos no tienen ningún poder directo ni indirecto en materia temporal sobre nuestros reyes ni sobre la jurisdicción secular. Segundo, que el poder del papa, en materia espiritual, no es absoluto en Francia, porque está limitado por los cánones y por las costumbres observadas en el reino; de suerte que aquello que el papa podría ordenar en perjuicio de esas reglas es nulo".

${ }^{145}$ En el texto completo, que a continuación transcribimos, se confunde la conversión 
iii) Separación entre el Estado y la Iglesia, que pretende deducirse de argumentos teológicos, para convencer a los ilustrados de alcurnia cristiana.

$\mathrm{Al}$ respecto, Romilly expone de modo impecable la doctrina católica acerca de los dos poderes temporal y espiritual: "Donc on ne réduira jamais la question à son véritable point, si lon ne distingue d abord l état de léglise et le prêtre du magistrat. L'état ou la république a pour but la conservation de ses membres, Passurance de leur liberté, de leur vie, de leur tranquillité, de leurs possessions et de leurs privileges: lEglise au contraire est une société, dont le but est la perfection de l homme et le salut de son ame. Le souverain regarde sur-tout la vie présente: I Eglise regarde sur-tout et directement la vie à venir. Maintenir la paix dans la société contre tous ceux qui voudroient y porter atteinte, c'est le devoir et le droit du souverain; mais son droit expire où regne celui de la conscience ${ }^{146}$.

De las premisas asentadas se podría deducir toda la doctrina clásica de los dos poderes. Lo temporal es distinto de lo espiritual, como lo inferior es distinto de lo superior. Ambos se distinguen, pero se subordinan, dado que un mismo sujeto, el hombre, es el destinatario de ambas sociedades, el Estado y la Iglesia. El Estado se subordina a la Iglesia en los intereses espirituales, y la Iglesia respeta la autonomía del Estado en los intereses puramente materiales. Sin embargo, el articulista extrae una conclusión diversa. De la distinción Iglesia-Estado no deduce cooperación y subordinación relativa sino separación absoluta: "Ces deux jurisdictions doivent toujours être séparées; elles ne peuvent empiéter l une sur lautre, qu' il n'en résulte des maux infinis" 147 .

Es decir, de la distinción entre las dos esferas y las dos sociedades nace una estricta separación. Separación que se reitera enseguida con la idea de que el Estado

forzada -siempre ilícita- con la defensa temporal de la fe ante los ataques también temporales de quienes desean exterminarla: "Mais, direz-vous encore, le prince est le défenseur de la foi; il doit la maintenir dans toute sa pureté, et s'opposer avec vigueur à tous ceux qui lui portent atteinte; si les raisonnemens, les exhortations, ne suffisent pas; ce n'est pas en vain qu'il porte l'épée, c'est pour punir celui qui fait mal, pour forcer les rébelles à rentrer dans le sein de l'Eglise. Que veux-tu donc, barbare? Égorger ton frere pour le sauver? Mais Dieu t'a-t-il chargé de cet horrible emploi, a-t-il remis entre tes mains le soin de sa vengeance? D'où sais-tu qu' il veuille être honoré comme les démons? Va, malheureux, ce Dieu de paix desavoue tes affreux sacrifices; ils ne sont dignes que de toi". Ibíd., s.v. Tolérance, cit. "Pero me diréis que el principio es la defensa de la fe; que debe mantenerse en toda sus pureza y oponerse con vigor a todos aquellos que la quieren herirla. Si los razonamientos, las exhortaciones no son suficientes... (no se puede) forzar a los rebeldes a volver al seno de la Iglesia [...]. Ese Dios de paz condena tus horribles sacrificios; ellos no son dignos más que de ti".

146 "Uno no reducirá la cuestión a su verdadero punto si no se distingue primero el Estado de la iglesia y el sacerdote del magistrado. El Estado o la república tiene por objeto la conservación de sus miembros, la protección de su libertad, de su vida, de su tranquilidad, de sus posesiones, de sus privilegios; la Iglesia al contrario es una sociedad, cuya meta es la perfección del hombre y la salud del alma. El soberano mira sobre todo a la vida presente; la Iglesia mira sobre todo y directamente a la vida por venir. Mantener la paz en la sociedad contra todos aquellos que quieren acarrearle un daño, es el deber y el derecho del soberano; más su derecho expira donde comienza el reino de la conciencia”. Ibíd.

147 "Las dos jurisdicciones deben siempre estar separadas; ellas no pueden usurparse recíprocamente, pues el resultado es de males infinitos”. Ibíd. 
no debe privilegiar con su legislación, bajo ningún respecto, el catolicismo ${ }^{148} \mathrm{ni}$ aún en un país como la Francia de la época, a la sazón, el Reino cristianísimo.

iv) La libertad de conciencia y de religión debe conducir al Estado laico.

Que la sociedad en su conjunto profese la fe católica o cristiana es un despropósito, pues, como hemos visto, convierte a dicha fe en una opresión de la conciencia individual. El incrédulo Diderot utiliza un epigrama de raíces bíblicas para probarlo: “Le Christ a dit. mon royaume n'est pas de ce monde; et vous,son disciple, vous voulez tyranniser ce monde? ${ }^{p 149}$.

O sea, Cristo hizo de su religión un fenómeno individual, y sus seguidores la han convertido en una verdad que inspira el orden político y social. El Estado laico debe sacudirse de este dominio, para que la sociedad y el gobierno sean libres y puedan disponer de lo que quieran según su arbitrio. Y el Evangelio tiene que reducirse a lo que es: una simple ética natural del sentimiento humanitario ${ }^{150}$.

\section{La Encyclopédie y el plan de separación entre la Iglesia y el Estado.}

La Encyclopédie establece un sólido vínculo entre la libertad de conciencia y de religión y la idea de Estado, ya completamente "moderno" en sus líneas esenciales.

En efecto, los ilustrados, cómo si conocieran los rumbos que abriría la Revolución Francesa, diseñan unas nuevas relaciones entre la Iglesia y el Estado, definidas por la separación entre ambos. Además configuran el principio de que el Estado es incompetente en materia de convicciones religiosas, por lo que su acción termina donde comienza la libertad de conciencia.

En la voz "Tolerance" 151 , luego de distinguir entre Iglesia y Estado según el orden de sus distintas finalidades, sintetizando, con acierto y habilidad, la tradición católica sobre el tema ${ }^{152}$, se establecen los derechos de la libertad de

148 "Le salut des ames n'est confié au magistrat ni par la loi révélée, ni par la loi naturelle, ni par le droit politique. Dieu n'a jamais commandé que les peuples fléchissent leur conscience au gré de leurs monarques, et nul homme ne peut s'engager de bonne foi à croire et à penser comme son prince l'exige. Nous l'avons déja dit: rien n'est plus libre que les sentimens; nous pouvons extérieurement et de bouche acquiescer aux opinions d'un autre, mais il nous est aussi impossible d'y acquiescer intérieurement et contre nos lumieres, que de cesser d'être ce que nous sommes [...], mais la religion se persuade et ne se commande pas". Ibíd.: "La salud de las almas no ha sido confiada al magistrado ni por ley revelada ni por ley natural, no por le derecho político. Dios no ha ordenado jamás que los pueblos doblen su conciencia según el gusto de sus monarcas, y ningún hombre puede creer de buena fe y pensar que su príncipe lo exije. Ya lo hemos dicho: nada es más libre que los sentimientos; podemos exteriormente y de boca para afuera asentir a las opiniones de otro, pero es imposible asentir interiormente y contra nuestras luces sin cesar de ser lo que somos. (Por eso) la religión se persuade y no se ordena".

${ }^{149}$ Ibíd.: "Cristo ha dicho: mi reino no es de este mundo; y vosotros, sus discípulos, queréis tiranizar ese mundo!”.

150 "Au reste il nous paroît inutile d'opposer aux intolérans les principes de l'Evangile, qui ne fait qu'étendre et développer ceux de l'équité naturelle". Ibíd., s.v. Tolérance, cit.: "Parece inútil oponer a los intolerantes los principios del Evangelio, que no hace más que ampliar y desenvolver la equidad natural".

${ }^{151}$ Ibíd., s.v. Tolerance, cit.

152 "Dans une matiere aussi délicate, je ne marcherai point sans autorité; et dans l'exposition 
conciencia frente al segundo, pero formulando, a la vez, de manera tan clara su preeminencia en cuestiones de fe, que no cabe sino reivindicarla también frente a la potestad indirecta que se atribuye la Iglesia en cuestiones político temporales de naturaleza moral ${ }^{153}$.

El paso hacia la separación definitiva entre la Iglesia y el Estado está dado por exigencia de los derechos de la conciencia humana frente a lo divino. Y la Encyclopédie consagra la conclusión sin ambages: " $V$. A ces principes, on nous opposera les inconvéniens qui résultent de la multiplicité des religions, et les avantages de P uniformité de croyance dans un état. Nous répondrons d' abord avec lauteur de lEsprit des Loix. '[...] la grandeur du génie ne consisteroit-elle pas mieux à savoir

de quelques principes généraux, on verra sans peine les conséquences qui en découlent. I. Donc on ne réduira jamais la question à son véritable point, si l'on ne distingue d'abord l'état de l'église etle prêtre du magistrat. L'état ou la république a pour but la conservation de ses membres, l'assurance de leur liberté, de leur vie, de leur tranquillité, de leurs possessions et de leurs privileges: l'Eglise au contraire est une société, dont le but est la perfection de l' homme et le salut de son ame. Le souverain regarde sur-tout la vie présente: l'Eglise regarde sur-tout \& directement la vie à venir. Maintenir la paix dans la société contre tous ceux qui voudroient y porter atteinte, c'est le devoir et le droit du souverain; mais son droit expire où regne celui de la conscience: ces deux jurisdictions doivent toujours être séparées; elles ne peuvent empiéter l'une sur l'autre, qu'il n'en résulte des maux infinis". Ibíd. ("En una materia tan delicada, yo no jarcharía sin autoridad; y en la exposición de algunosmprincioios geherales se verá sin esfuerzo las consecuencias que se deslizan. I. Uno no reducirá la cuestión a su verdadero punto si no se distingue primero el estado de la iglesia y el sacerdote del magistrado. El estado o la república tiene por objeto la conservación de sus miembros, la protección de su libertad, de su vida, de su tranquilidad, de sus posesiones, de sus privilegios; la Iglesia al contrario es una sociedad, cuya meta es la perfección del hombre y la salud del alma. El soberano mira sobre todo a la vida presente; la Iglesia mira sobre todo y directamente a la vida por venir. Mantener la paz en la sociedad contra todos aquellos que quieren acarrearle un daño, es el deber y el derecho del soberano; más su derecho expira donde el reino comienza el reino de la conciencia. Las dos jurisdicciones deben siempre estar separadas; ellas no pueden usurparse recíprocamente, pues el resultado es de males infinitos").

${ }^{153}$ La Encyclopédie dice: "la salud de las almas no ha sido encomendada al magistrado", de lo que deduce que el Estado no es competente en materia religiosa. Pero a reglón seguido agrega el principio general de inspiración rousseauniana de que "nada es más libre que los sentimientos"y que la "religión persuade pero no ordena" porque de lo contrario se atenta contra nuestra personalidad, con lo que se excluye la autoridad magisterial de la Iglesia respecto del poder político. He aquí el texto que debe leerse con gran detención para captar todo su sentido: "II. En effet le salut des ames n'est confié au magistrat ni par la loi révélée, ni par la loi naturelle, ni par le droit politique. Dieu n'a jamais commandé que les peuples fléchissent leur conscience au gré de leurs monarques, et nul homme ne peut s'engager de bonne foi à croire et à penser comme son prince l'exige. Nous l'avons déja dit: rien n'est plus libre que les sentimens; nous pouvons extérieurement et de bouche acquiescer aux opinions d'un autre, mais il nous est aussi impossible d'y acquiescer intérieurement et contre nos lumieres, que de cesser d'être ce que nous sommes [...] mais la religion se persuade et ne se commande pas" Ibíd.: ("II. En efecto, la salud de las almas no ha sido confiada al magistrado ni por ley revelada ni por ley natural, no por le derecho político. Dios no ha ordenado jamás que los pueblos doblen su conciencia según el gusto de sus monarcas, y ningún hombre puede creer de buena fe y pensar que su príncipe lo exige. Ya lo hemos dicho: nada es más libre que los sentimientos; podemos exteriormente y de boca para afuera asentir a las opiniones de otro, pero es imposible asentir interiormente y contra nuestras luces sin cesar de ser lo que somos. (Por eso) la religión se persuade y no se ordena"). 
dans quels cas il faut de ' uniformité, et dans quels cas il faut des différences'. En effet, pourquoi prétendre à une perfection incompatible avec notre nature? La diversité des sentimens subsistera toujours parmi les hommes; l histoire de lesprit humain en est une preuve continuelle; et le projet le plus chimérique seroit celui de ramener les hommes à Puniformité d'opinions./ Cependant, dites-vous, lintérêt politique exige qu'on établisse cette uniformité; qu'on proscrive avec soin tout sentiment contraire aux sentimens reçus dans l'état, c' est-à-dire, qu'il faut borner l homme à n' être plus qu' un automate, à linstruire des opinions établies dans le lieu de sa naissance, sans jamais oser les examiner, ni les approfondir, à respecter servilement les préjugés les plus barbares, tels que ceux que nous combattons. Mais que de maux, que de divisions n'entraîne pas dans un état la multiplicité de la religion? L'objection se tourne en preuve contre vous, puisque lintolérance est elle-même la source de ces malheurs" 154 .

La referencia del último párrafo a los males de la intolerancia del Estado confesional es sintomática para percibir el presupuesto escéptico que alimenta la libertad ilustrada de conciencia y de religión: la armonía sólo puede provenir del respeto mutuo a las diversas religiones, porque éstas no son más que asuntos de "sentimiento" y de "opiniones" subjetivas. La verdad religiosa no tiene nada que decir sobre la orientación de lo político.

Pero Romilly, el autor del artículo, es hábil. Comienza hablando el lenguaje de la tolerancia (que implica soportar un mal, cual sería, el error religioso) para terminar invocando la libertad de conciencia y de religión, que supone que en materia religiosa sólo hay opiniones (no existe la "verdad" o el "error" religioso) y que el poder político no puede vincularse a subjetividades de esta clase. La diversidad de religiones en este contexto es un bien en sí mismo porque vuelve verosímil el principio filosófico escéptico que funda la interrelación entre laicismo y libertad religiosa.

Podemos ver cómo la Encyclopédie construye el ideal de Estado laico teniendo como fundamento la libertad moderna de conciencia y de religión. Pero ésta es una cara de la moneda. La otra es que el poder estatal se vuelve soberano y no reconoce barreras extra-estatales, como las derivadas del principio de trascendencia: la ley divino-natural, por ejemplo. Es más, a partir de aquí surge la afirmación

${ }^{154}$ Ibíd.: "V. A esos principios, se nos puede oponer el inconveniente que resulta de la multiplicidad de religiones y las ventajas de la uniformidad de creencias en un estado. Nosotros respondemos primero con el autor del Espíritu de las leyes: "[...] la grandeza del genio consiste en saber en cuales casos es necesaria la uniformidad y en cuales casos es necesaria la diferencia”. En efecto, por qué pretender una perfección incompatible con nuestra naturaleza? La diversidad de sentimientos subsistirá siempre entre los hombres; la historia del espíritu humano es una prueba continua, y el proyecto más quimérico sería reducir a los hombres a una uniformidad de opiniones./ Entretanto, se me dirá, el interés político exige que se establezca esta uniformidad; que se proscriba con cuidado todo sentimiento contrario a los sentimientos recibídos en el Estado; es decir, es necesario limitar al hombre para que no sea más que un autómata, instruirlo con opiniones estables desde su nacimiento, sin que jamás ose examinarlas, ni profundizarlas; que respete servilmente los prejuicios más bárbaros, tales como aquellos que nosotros combatimos. ¿Qué hay de malo para un Estado la división que entraña la diversidad de religiones? La objeción se vuelve contra vos, porque la intolerancia es ella misma la fuente de los males". 
filo-totalitaria que ya se han visto en otros pensadores modernos: es el Estado el único competente para conocer las cuestiones morales y religiosas en el espacio público. El poder político tiene el deber de juzgar y decidir como instancia suprema en tales materias, porque éstas no deben interceptar el interés público que él representa y define. Al respecto precisa la Encyclopédie: "IV. On peut tirer de ces paroles ces conséquences légitimes ${ }^{155}$. La premiere, c'est que les souverains ne doivent point tolérer les dogmes qui sont opposés à la société civile; ils n'ont point, il est vrai, d' inspection sur les consciences, mais ils doivent réprimer ces discours téméraires qui pourroient porter dans les coeurs la licence \& le dégoût des devoirs. Les athées en particulier, qui enlevent aux puissans le seul frein qui les retienne, [...] ne doivent pas réclamer la tolérance en leur faveur; $2^{\circ}$. Les souverains doivent s'opposer avec vigueur aux entreprises de ceux qui couvrant leur avidité du prétexte de la religión; $3^{\circ}$. Sur-tout qu'ils proscrivent avec soin ces sociétés dangereuses, qui soumettant leurs membres à une double autorité, forment un état dans létat, rompent l union politique, relâchent, dissolvent les liens de la patrie pour concentrer dans leur corps leurs affections et leurs intérêts, et sont ainsi disposés à sacrifier la société générale à leur société particuliere. En un mot, que létat soit un, que le prêtre soit avant tout citoyen; qu'il soit soumis, comme tout autre, à la puissance du souverain, aux loix de sa patrie; que son autorité purement spirituelle se borne à instruire, à exhorter, à prêcher la vertu; qu' il apprenne de son divin maître que son regne n'est pas de ce monde; car tout est perdu, si vous laissez un instant dans la même main le glaive et lencensoir" ${ }^{\prime 156}$.

${ }^{155}$ Se refiere al texto del Contrato Social de Rousseau que cita como regla III: "III. Expliquons-nous donc librement, et empruntons le langage de l'auteur du contrat social. "Le droit que le pacte social donne au souverain sur les sujets, ne passe point les bornes de l'utilité publique; les sujets ne doivent donc compte au souverain de leurs opinions, qu'autant que ces opinions importent à la communauté. Or il importe bien à l'état que chaque citoyen ait une religion qui lui fasse aimer ses devoirs; mais les dogmes de cette religion n'intéressent l'état, ni ses membres, quautant qu'ils se rapportent à la société. Il y a une profession de foi purement civile, dont il appartient au souverain de fixer les articles, non pas précisément comme dogmes de religion, mais comme sentimens de sociabilité, sans lesquels il est impossible d'être bon citoyen, ni sujet fidele, sans pouvoir obliger personne à les croire; il peut bannir de l'état quiconque ne les croit pas, non comme impie, mais comme insociable, comme incapable d'aimer sincerement les loix de la justice, et d'immoler au besoin sa vie à son devoir". Ibíd.: ("III. Expliquémonos libremente y utilicemos el lenguaje del autor del contrato social: "El derecho que el pacto social da al soberano sobre los súbditos, no pasa más allá de los límites de la utilidad pública; los súbditos no deben pues rendir cuentas al soberano de sus opiniones, en tanto que esas opiniones importen a la comunidad. Lo que importa es que en el Estado cada ciudadano tenga una religión que le haga amar sus deberes; mas los dogmas de esa religión no interesan al estado, ni a sus miembros, en tanto que ellos se relacionen con la sociedad. Hay una profesión de fe puramente civil, porque corresponde al soberano fija los artículos, no precisamente como dogmas de religión, mas como sentimientos de sociabilidad, sin los cuales es imposible ser buen ciudadano, ni súbdito fiel. No se puede obligar a nadie a creer, pero se puede expulsar del estado a quienquiera que no crea, no como impío, sino como insociable, como incapaz de amar sinceramente la ley de la justicia, y de inmolar si es necesario su vida a su deber”): Ibíd.

156 "IV. Uno puede sacar de estas palabras las consecuencias legítimas. La primera es que los soberanos no deben tolerar los dogmas que son opuestos a la sociedad civil; ellos no tienen, es verdad, inspección sobre las conciencias, pero ellos deben reprimir esos discursos temerarios que podrían acarrear la licencia y el hastío de los deberes. Los ateos, en particular, 
El principio del Estado fundado en el laicismo militante está consagrado aquí. Y con él la lógica de la descristianización forzada que puso en obra la Revolución Francesa en consonancia con esta doctrina.

La vigencia universal de la libertad de conciencia y de religión sigue presente, pero trazada en estado de combate, como instrumento de lucha contra la verdad católica aceptada y abrazada por la sociedad. Empero, emerge un espacio de tensión. Dado que el Estado es quien, en definitiva, delimita lo bueno y lo malo para la sociedad, la libertad de conciencia y de religión que emancipa al hombre, corre ahora el riesgo de ser encarcelada con una nueva definición de lo público, en donde lo individual no cuenta a la hora de exaltar la defensa de lo colectivo.

En síntesis, las libertades modernas emancipan al hombre individual y hacen posible la emancipación de lo colectivo a través de un Estado que se construye a sí mismo separándose de la Iglesia y sometiéndola a sus dictados, dado que no es admisible la existencia de un état dans l état. A partir de la hipóstasis del poder en el Estado laico, todos los espacios sociales quedan sometidos a su mirada purificadora. Una vez consolidado el proyecto secularizador del orden político, lo individual queda de alguna manera absorbido en lo colectivo, abriéndose una posibilidad de tensión entre los dos canales del Estado y de la libertad. De ahí que toda la exaltación enciclopedista de la libertad de conciencia y de religión esté condicionada por esta afilada regla: "Respectez inviolablement les droits de la conscience dans tout ce qui ne trouble point la sociétê" ${ }^{157}$.

\section{CONCLUSIÓN}

La libertad de conciencia y de religión es, en gran parte, un compuesto que proviene de un lenguaje ambiguo. Los términos apuntan a un significado más restringido de lo que, en una primera lectura, se sugiere. A este respecto, es notable constatar cómo en los escritos de Voltaire y la Encyclopédie dicha libertad se reputa por esencia y por sistema desvinculada del Dios cristiano. La conciencia

que quitan al poder el solo freno que les retiene ... no deben reclamar tolerancia en su favor. $2^{\circ}$ Los soberanos deben oponerse con vigor a las empresas de aquellos que cubren su avidez con el pretexto de la religión [...]. 30 Sobre todo han de proscribir con atención esas sociedades peligrosas, que someten a sus miembros a una doble autoridad, forman un estado dentro del estado, rompen la unión política, relajan, disuelven los vínculos de la patria para concentrar en su cuerpo sus afecciones y sus intereses, y son así dispuestos a sacrificar la sociedad general a su sociedad particular. En una palabra, que el estado sea uno, que el cura sea también ciudadano; que sea sumiso, como todos, al poder del soberano, a las leyes de su patria; que su autoridad puramente espiritual se limite a instruir, a exhortar, a predicar la virtud; que aprenda de su divino maestro que su reino no es de este mundo, porque todo está perdido si se deja un instante en la misma mano la espada y el incensario". Ibíd.:

157 "Regle générale. Respectez inviolablement les droits de la conscience dans tout ce qui ne trouble point la société. Les erreurs spéculatives sont indifférentes à l'état; la diversité des opinions régnera toujours parmi des êtres aussi imparfaits que l' homme; la vérité produit les hérésies comme le soleil des impuretés et des taches" "Regla general. Respetar inviolablemente los derechos de la conciencia en todo aquello que no trastorne la sociedad. Los errores especulativos son indiferentes al estado; la diversidad de opiniones regenera siempre a seres tan imperfectos como los hombres; la verdad produce las herejias como el sol las impurezas y las manchas"). Ibíd. 
moral ha dejado de ser testimonio de una ley objetiva -la ley divino-natural- y se convierte en expresión pura de la propia soberanía individual. La libertad se constituye como facultad reivindicatoria que pulsa por vivir sin ligamen externo trascendente, atenta a los impulsos sensibles de la sola naturaleza humana.

Es el agnosticismo religioso y el escepticismo metafísico, sellados por el furor anti-cristiano, el que vivifica el fundamento ilustrado de la libertad de conciencia y de religión. Concebida bajo apariencias neutrales (ahí radica su engaño) es en realidad una voluntad de librarse - por la fuerza si es necesario- de la conciencia cristiana y de la religión católica en la vida individual, social y política de los pueblos europeos y después hispanoamericanos. Lo que desde el ángulo político comporta la exigencia de separación entre la Iglesia y el Estado como principio axiológico-constitucional y la reducción de la religión al estatuto de mera opinión o creencia subjetiva.

En este lenguaje, que es el de Voltaire y la Encyclopédie,ser tolerante quiere decir en concreto excluir la fe y la moral cristianas de la vida pública, obra en la que se empeñará la Revolución de 1789, y después, su heredera, la III República francesa, consumando el proceso de secularización de la Modernidad política.

Tras la tolerancia y la libertad ilustrada se deja ver, como la cara tras la máscara, el proceso contra el Dios cristiano, del que habla Hazard, pero también y especialmente contra el orden político y temporal heredado (y en esa misma medida) de la Cristiandad. A nivel político, es lo que teorizará Rousseau.

\section{BibLIOGRAFÍA}

ADAM, Antoine, Le Mouvement philosophique dans la premiere moitie du XVIIIe siècle (Paris, S.e.d.e.s., 1967).

Balet Roca, Sebastián, Le deisme anglais et le probleme de la religion de Voltaire, en Cuadernos de Investigación Filológica, 6 (Logroño, 1980).

BELLO, Eduardo, Tolerancia, verdad y libertad de conciencia en el siglo XVIII, en Isegoría, 30 (Madrid, 2004).

Benítez, Miguel, Anthony Collins revisitado: deismo, panteísmo y ateísmo en los tiempos modernos, en Daimon. Revista de Filosofía, de la Universidad de Murcia, 41 (2007).

Besterman, Theodore y otros, Studies on Voltaire and the Eighteenth Century (Oxford, The Voltaire Foundation, 1956-2010).

Besterman, Theodore, Voltaire's Notebooks (Gonève, Publications de l'Institut et Musée Voltaire, 1952).

BLom, Philipp, Encyclopédie. El triunfo de la razón en tiempos irracionales. Historia de la elaboración de la Enciclopedia (1751-1780) (Barcelona, Anagrama, 2007).

CLEMENTE XIII, encíclica Utprimum del 3 de septiembre de 1759 [http://fr.wikisource. org/wiki/Encyclique_du_pape_Cl\%C3\%A9ment_XIII].

ColuIns, Anthony, A Discourse of Freethinking, Occasioned by the Rise and Growth of a Sect called Freethinkers [edición de Londres, 1713, en http://books.google.es/book s?id=IUsJAAAAQAAJ\&printsec $=$ frontcover\&dq=Anthony+Collins,+ Discourse + of +Freethinking\&source=bl\&ots=oUdQr1nds2\&sig=mShC7LhwgFGBNGuTt8 
acBhJqRM\&hl=es\&ei=Xi7rS5aoPIHaQb4huDCBA\&sa=X\&oi=book_result\&c $\mathrm{t}=$ result\&resnum $=3 \& \mathrm{ved}=0 \mathrm{CC} 4 \mathrm{Q} 6 \mathrm{AEwAg} \# \mathrm{v}=$ onepage $\& \mathrm{q} \& \mathrm{f}=$ false $]$.

DE Viguerie, Jean, Histoire et Dictionnaire du temps des Lumières (Paris, Laffont, 1995).

Delumeau, Jean, Le catholicisme entre Luther et Voltaire (Paris, P. U.F, 1971).

DesnoIresterres, Gustave, Voltaire et la Société au XVIIIe siècle (Paris, Didier, 18671876).

Diderot, Denis - D’Alambert, Jean le Rond, Encyclopédie o Dictionnaire raisonné des sciencies, des arts et des métiers (junio de 1751 a diciembre de 1765), edición digital completa de Flammarion - Le Monde: [http://diderot.alembert.free.fr/].

Estermann, Josef, Historia de la Filosofía (Traducción Quito, Ed. Salesiana, 1997).

Gallo, Max, Moi, jécris pour agir: vie de Voltaire (Paris, Fayard, 2008).

GoldzInK, Jean, Voltaire, la légende de saint Arouet (Paris, Gallimard, 1989).

Granada, M. A. - Rius, R. - Schiavo, P. (editores), Filósofos, filosofía y filosofías en la Encyclopédie de Diderot y d'Alembert (Barcelona, Publicacions i Edicions Univ. Barcelona, 2009).

Gusdorf, Georges, Les Sciences humaines et la pensée occidentale (Paris, Payot, 1971).

GuYOn, Claude-Marie, L'oracle des nouveaux philosophes: Pour servir de suite et déclaircissemen aux oeuvres de M. de Voltaire, A. Berne, 1760-1765 [El Oráculo de los nuevos philosofos, M. Voltaire, impugnado y descubierto en sus errores por sus mismas obras, traducida por Fr. Pedro Rodríguez Morzo [el autor figura anónimo], Imprenta de Gabriel Ramírez, Madrid, 1769 (Vol. I) y 1770 (Vol. II).

Hazard, Paul, La Pensée européenne au XVIIIe siècle, de Montesquieu à Lessing (Paris, Librairie Arthème Fayard, 1979) [El pensamiento europeo en el siglo XVIII (traducción castellana de Julián Marías, Madrid, Alianza, 1985)].

KorfF, Hermann Augus, Voltaire im literarischen Deutschland des 18 (Heidelberg, Zweites Buch, 1918).

LEPAPE, Pierre, Voltaire le conquerant. Naissance des intellectuels au siècle des Lumiéres. Essai (Paris, Seuil, 1997).

Manent, Pierre, Histoire intellectuelle du libéralisme: dix leçons (1987, rééd. Paris, Hachette, 2004) Historia del pensamiento liberal (traducción Buenos Aires, Emecé, 1990)"|.

Martin, Xavier, Nature humaine et Révolution française: Du siècle des Lumières au Code Napoleón (Paris, Dominique Martin Morin, 2002).

Martin, Xavier, Voltaire méconnu: aspects cachés de l humanisme des Lumières (17501800) (Paris, Dominique Martin Morin, 2006).

Mornet, Daniel, La Pensée française au XVIIIe siècle (Paris, Colin, 1926) [El pensamiento francés en el siglo XVIII: el trasfondo intelectual de la Revolución francesa (Madrid, Encuentro, 1988)].

Mornet, Daniel, Les origines intellectuelles de la Révolution française, 1715-1787 (Paris, Colin, 1933) [Los origenes intelectuales de la Revolución Francesa (Buenos Aires, Paidos, 1969)|

NoYes, Alfred, Voltaire (London, Sheed \& Ward, 1936).

OCÁRIZ, Fernando, Voltaire. Tratado sobre la tolerancia (Madrid, Crítica-Emesa, 1979).

PAInE, Thomas, The Age of Reason, Being an Investigation of True and Fabulous Theology (1794, 1795 y 1807, New York, Philip Sheldon Foner, 1974). 
Peyrefitte, Roger, Voltaire, sa jeunesse et son temps (Paris, Albin Michel, 1985).

Pomeau, René (editor), Voltaire en son temps (Paris, Fayard, 1995).

Pomeau, René, La Religión de Voltaire (Paris, Nizet, 1956).

Pomeau, René, Voltaire en son temps (Oxford - Paris, Voltaire Foundation-Fayard, 1985-1994).

Pujol, Carlos, Voltaire (Palabra, Madrid, 1999).

SÉvillia, Jean, Historiquement correct. Pour en finir avec le passé unique (Paris, Perrin, 2003) [Históricamente incorrecto (traducción Madrid, Ciudadela, 2006)]

Teodorov, Tzvetan, L'Esprit des Lumières (Paris, Laffont, 2006).

Torrey, Noman, Voltaire and the English Deists (New Haven, Yale University Press, 1930, reimp. 1963).

Trousson, Raymond - Vercruysse, Jeroom, Dictionnaire général de Voltaire par luimême (Paris, Champion, 2003).

Trousson, Raymond, Voltaire 1778-1878 (Paris, PUPS, 2008).

Versaille, André (editor), Dictionnaire de la pensée de Voltaire (Bruxelles, éditions Complexe, 1994).

Villacañas Berlanga, José Luis, Historia de la razón y giro copernicano, en Logos. Anales del Seminario de Metafísica, 37 (Madrid, 2004).

Voltaire, Cartas filosóficas, edición completa de la Biblioteca digital Ciudad Seva en: http://www.ciudadseva.com/textos/otros/voltaire/carfilo/indice.htm].

VolTaire, Diccionario filosofico (Madrid, Temas de Hoy, 1995).

Voltaire, Dictionnaire philosophique (1764, Paris, Louis Moland chez Garnier, 18701880) [versión digital en: http://www.voltaire-integral.com/Html/20/religion. htm].

Voltaire, Examen important de Milord Bolingbroke ou le tumbeau du fanatisme, en Oeuvres de Voltaire (1736, edición Paris, Pourrat Frères, 1839), II: Philosohie.

Voltaire, Poème sur le désastre de Lisbonne ou Examen de cet axiome, tout est bien [edición digital en: http://fr.wikisource.org/wiki/Po\%C3\%A8me_sur_ le_d\%C3\%A9sastre_de_Lisbonne].

Voltaire, Profession de foi des Theistes, en Oeuvres de Voltaire (1768, edición Paris, Pourrat Frères, 1839), II: Philosohie.

Voltaire, Traité de Métaphysique, en Oeuvres complètes de Voltaire (Baudouin Frères, París), XLIII: Philosohie, 1.

VolTAire, Traitésur la Tolérance a l'occasion de la mort de Jean Calas, 1763, en Oeuvres complètes de Voltaire, Mélanges IV (1763-1766), edición de Kehl [versión electrónica: http://www.voltaire-integral.com/Html/25/01_Table_Tolerance.html].

WaterLot, Ghislain, Voltaire: le procureur des Lumières (Paris, Michalon, 1996). 